\title{
Holocene site occupancy in Sulawesi
}

\author{
David Bulbeck
}

\begin{abstract}
This contribution presents an analysis of the number of Sulawesi sites (summed probability) occupied per 500-year interval between 10,000 and $0 \mathrm{BP}$, based on radiometric dates. The number of occupied sites was low between 10,000 and $4500 \mathrm{BP}$, ranging between 1 to 4 per half-millennium. There were subsequent increases in the number of occupied sites per halfmillennium to 5-8 between 4500 and 2000 BP, 9-13 between 2000 and 1000 BP, and over 30 between 1000 and 0 BP. These figures would be consistent with a scenario of substantial population increases at around 4500, 2000 and 1000 BP. However, care should be exercised in making a literal interpretation of these figures. For instance, with respect to the 4500-2500 BP period, the number of closed sites was highest during 4500-3500 BP and the number of openair sites highest during 3500-2000 BP. Also, the large number of documented sites dating to the last millennium BP reflects a particular focus of Sulawesi archaeological research on sites related ethnohistorically to the Bugis and other major ethno-linguistic divisions in South Sulawesi.
\end{abstract}

Keywords: Sulawesi Holocene, site occupancy, summed probabilities, closed sites, open-air sites

\section{Introduction}

The increased availability of radiometric determinations from archaeological sites has encouraged archaeologists to use these dates as a proxy measure for population levels in times past. Peros et al. (2010) and Williams (2012) outline the history and growing popularity of this approach, and its respective application to North America and Australia-two continents for which there are large numbers of radiocarbon dates from archaeological sites. The statistical basis for their analysis is to calibrate the dates, distribute the resulting calibrated probabilities across brief intervals and to sum the probabilities for each of the analytical intervals, followed by correction of the calculated numbers for factors such as the increasing probability of taphonomic loss of archaeological deposits with age and the perturbations inherent in the calibration curve (Peros et al. 2010; Williams 2012). While these two studies used the results to construct a scenario of continent-level changes in population size following initial colonisation, the same basic approach has been applied to more targeted research questions, such as the nature of the demographic transition in Europe following the early to mid-Holocene introduction of agriculture (Downey et al. 2014).

One pointed criticism of this approach is the possibility of a particularly intensive program of obtaining radiometric dates from certain sites compared with others, resulting in a biased representation of the periods of site occupancy represented by the intensively studied sites 
(Hiscock and Attenbrow 2016). Examples of Sulawesi sites represented by large numbers of radiometric determinations include the Gua Talimbue cave site in Southeast Sulawesi and the Minanga Sipakko open site in West Sulawesi. A solution to this objection is to employ the determinations to estimate the probabilities of site occupancy per specified interval (here, half-millennium intervals BP), and to sum these probabilities as an estimate of the number of occupied sites per interval. Then, in fact, there would arguably be a reversal in the bias; specifically, that a certain interval at a given site represented by a single unsupported date may be as prominent (up to $100 \%$ occupancy probability) as another interval at the same site represented by multiple confirmatory dates (see Discussion). Also, there remains the potential objection of bias in the types of sites focused on, although this issue can be addressed by examining the research programs covered by the radiometric determinations and is open to correction in the future as novel research programs are initiated.

A particularly thorny issue is which determinations to accept for analysis. My general approach here is to include dates if clearly from an archaeological context, and to reject dates only if there are positive reasons for their rejection. The justifications for this approach include: (1) to allow the inclusion of dates back to the 1970s for sites that have not since been re-excavated; (2) to incorporate dates processed in Indonesia for excavations undertaken by Indonesian archaeologists without foreign collaboration; and (3) to avoid subjective decisions of dates' acceptability-for instance, whether they 'fit' the excavator's expectations based on dates obtained from other sites or even the same site. In accord with this last point, when a date is rejected the decision is made whether or not the date is compatible with the a priori expectation of the dated material's radiometric determination. For instance, the median Carbon-14 date of 7170 BP from basal Ulu Leang 2 (ANU 1606, Table A8.1) is entirely compatible with the Carbon-14 dates obtained from higher in the site's deposit, but the large standard error of 600 years makes the determination useless for pinning down the probabilities of the 'real age' by half-millennium intervals BP (cf. Spriggs 2003).

Table A8.1 in Appendix A lists the radiometric dates from Sulawesi rejected for the purposes of the present analysis and the reasons for their rejection. In the future, when the archaeology of Sulawesi is better documented, it may be feasible to impose stricter criteria on the acceptance of radiometric determinations-for instance, to exclude any Carbon-14 dates that are not Accelerator Mass Spectrometry (AMS) dates-and to still have a sufficiently large sample of dated sites to produce a robust scenario of Holocene site occupancy patterns. For present purposes, analytical time intervals of 500 years (Bulbeck 2014) are employed to accommodate the motley assemblage of accepted determinations with alternatively wide and tightly defined standard errors (Tables A8.2-A8.6).

Note that Sulawesi in this contribution is defined to include the main body of the island and any immediately offshore islands (Figure 8.1). The Sangihe and Talaud island chains, while politically part of Sulawesi, lie approximately halfway from North Sulawesi to Mindanao in the Philippines and so are not considered here to be geographically part of Sulawesi. 


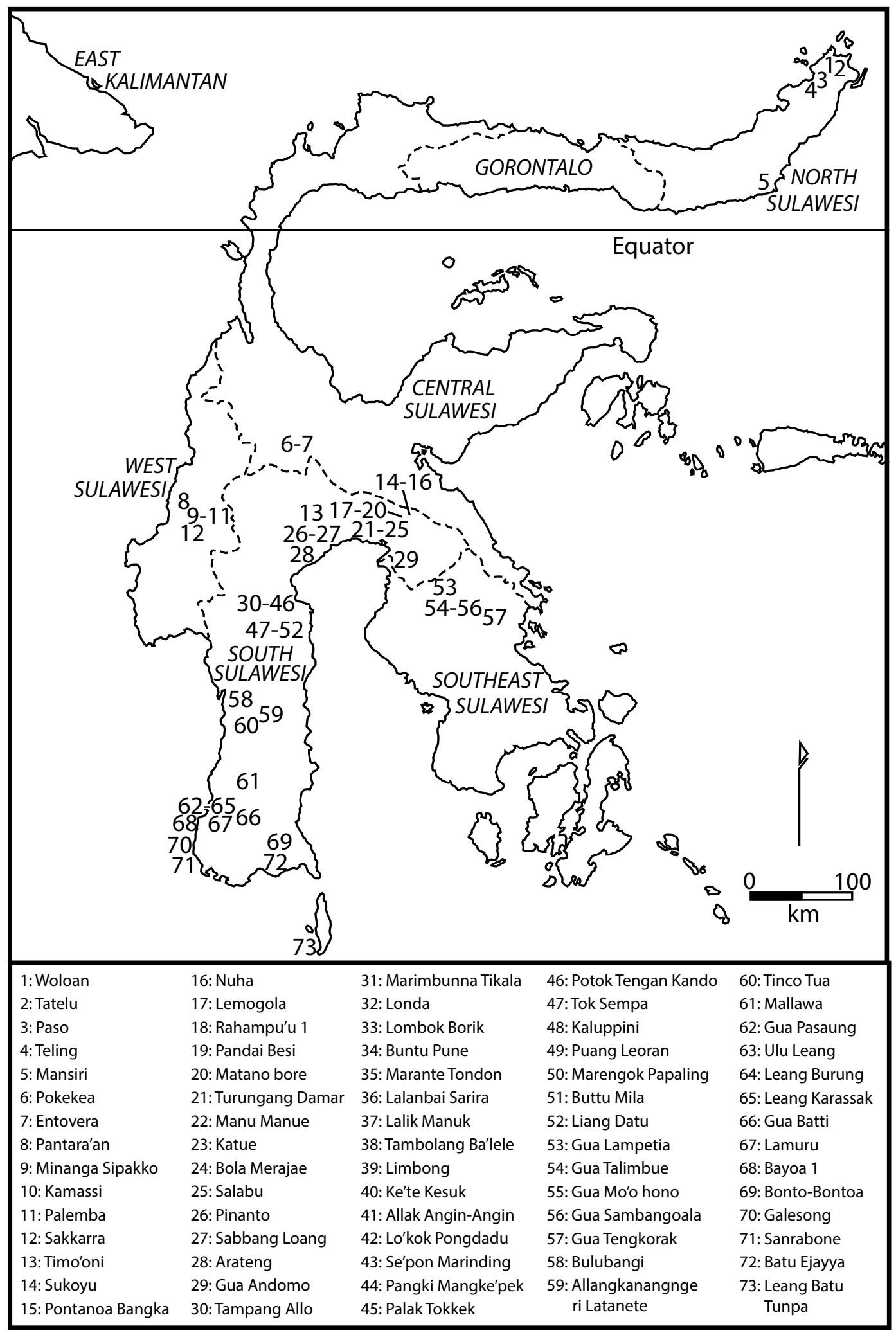

Figure 8.1: Sites in Sulawesi that have yielded accepted radiometric determinations. Source: Tables A8.2-A8.7. 


\section{Hypotheses on changes in Sulawesi past population sizes}

An overall scenario of population size increases in ISEA is posited by Brandão et al. (2016) from their analysis of mitochondrial DNA haplogroups found in recent ISEA populations. They infer low population sizes during the Pleistocene, followed by a 19-fold increment, which commenced around 10,500-8000 years ago, and a further 70-fold increment starting at around 4000 years ago. They relate the first of the inferred population expansions to the early Holocene stabilisation of sea levels in ISEA following the drastic rises of sea levels during the terminal Pleistocene. The second population expansion is related to the immigration of Austronesian speakers from Taiwan into ISEA (where the great majority of indigenous languages are Austronesian) commencing at around $4500 \mathrm{BP}$, and probably involved increasing numbers of both the genes introduced by immigrant Austronesians and the autochthonous genes established in ISEA prior to the Austronesian incursion.

The first of the inferred population expansions is not directly tested in this study but one reason for starting the analysis at 10,000 BP is the scarcity of ISEA radiometric dates relating to the terminal Pleistocene-for instance, to my knowledge there are just two radiometric determinations for Sulawesi with a median age between 20,000 and 10,000 BP, both from the single site of Gua Talimbue (O'Connor et al. 2014). In contrast, as we shall see, the millennia after 10,000 BP are consistently represented by radiometric determinations, compatible with the persistence of sustainable population sizes.

The second of the inferences by Brandão et al. (2016) would predict an increase in occupied sites starting at around $4000 \mathrm{BP}$. However, as explicitly noted by the authors, this would not rule out major steps in population size (and numbers of occupied sites) at later times. For instance, my research into the early historical archaeology of Southwest Sulawesi has led me to postulate watersheds in population size growth at approximately 2000 BP and 750 BP (Bulbeck 2010).

\section{Materials and methods}

This study accepts radiometric determinations of Holocene age (Tables A8.2 to A8.6) from 73 archaeological sites in Sulawesi. As shown in Figure 8.1, large swathes of Sulawesi remain undocumented for their archaeological chronology, including all of Gorontalo Province, almost all of Central Sulawesi Province and the southern four-fifths of Southeast Sulawesi Province. Even in South Sulawesi, which is the province with by far the best documented archaeology, there are large gaps in the geographic coverage. Accordingly, there is ample scope for future archaeological research to test the scenario of Holocene site occupancy generated here from the currently available data.

The available radiometric determinations are characterised in terms of the class of dated material, site aspect and site use (detailed in Bulbeck 2014, 2016). The seven dated material classes in order of precedence are 'Ceramic' (including dates from charcoal extracted from ceramic objects), 'Boat' (including boat-shaped coffins), 'Human bone', 'Marine shell', 'Charcoal', 'Animal matter' and 'Plant matter'. The 'Ceramic' and 'Boat' classes are of particular interest for dating these important developments in Sulawesi's prehistoric technology. The site aspect categories in order of precedence are 'Closed', 'Monumental' (megalithic sites in the context of this study), 'Maritime' (no examples for Sulawesi), 'Marine shell midden', 'Freshwater shell midden' and 'Open' (where none of the preceding applies). The site usage categories in order of precedence are 'Mortuary', 'Ceremonial' (for ritual contexts lacking strong evidence of a mortuary association), 'Industrial', 'Transport' (no examples for Sulawesi), 'Gardening' (especially charcoal probably related to forest clearance) and 'Habitation' (where none of the preceding applies).

\section{terra austiralis 48}


Site occupancy is analysed in terms of the probability of occupation during any 500-year interval between 10,000 and $0 \mathrm{cal}$ BP. The Carbon-14 (including AMS) dates were calibrated using the OxCal 13 internet program (Bronk Ramsey 2013). The program includes a capacity to distribute the $100 \%$ probability of the date's antiquity across five-year intervals, allowing these probabilities to be summed to 500-year intervals cal BP. The calibration of these dates did not include any correction factor for southern hemisphere determinations, in view of the proximity (within $6^{\circ}$ ) of all of the dated sites to the equator (Figure 8.1). The small number of accepted determinations that required a marine reservoir correction factor or that were a luminescence date were modelled as normal distributions in order to be assigned to 500-year intervals (cal) BP. (Note that in the Results and Discussion sections, the terminology 'BP' is used instead of 'cal BP', so as to incorporate luminescence dates, which do not require calibration.)

For the sake of explanation, we can use the Mallawa determinations, which are all dates on 'Charcoal' from 'Habitation' usage in an 'Open' site aspect (Table A8.6). The calibrated date probabilities span the 10 half-millennia between $5000-4500 \mathrm{cal} \mathrm{BP}$ and 500-0 cal BP. As these are the probabilities of occupation, their complements equate to the probabilities that the date does not document any occupation during the half-millennium in question. The product of the complements equates to the probability that none of the dates document occupation during the said half-millennium, and so the complement of the product equates to the joint probability of occupation at the site during the said half-millennium. This mathematical procedure (grounded in classical probability theory) caps the probability of occupation during any half-millennium to $1(100 \%)$, whilst allowing multiple dates that relate to a half-millennium to be used in consort to increase the overall probability of site occupation, up to a maximum of 1 (Table 8.1).

Table 8.1: Occupation probabilities of Mallawa by half-millennium cal BP.

\begin{tabular}{|c|c|c|c|c|c|c|c|c|c|c|c|}
\hline Date & $\begin{array}{r}5-4.5 \\
k B P\end{array}$ & $\begin{array}{r}4.5-4 \\
k \text { BP }\end{array}$ & $\begin{array}{r}4-3.5 \\
\text { k BP }\end{array}$ & $\begin{array}{r}3.5-3 \\
k B P\end{array}$ & $\begin{array}{r}3-2.5 \\
k B P\end{array}$ & $\begin{array}{r}2.5-2 \\
k B P\end{array}$ & $\begin{array}{r}2-1.5 \\
k B P\end{array}$ & $\begin{array}{l}1.5-1 \\
k B P\end{array}$ & $\begin{array}{r}1-0.5 \\
k B P\end{array}$ & $\begin{array}{r}0.5-0 \\
k \text { BP }\end{array}$ & Sum \\
\hline P3G-06 & 0.001 & 0.273 & 0.718 & 0.008 & & & & & & & 1.0 \\
\hline P3G-06 & & & 0.001 & 0.137 & 0.704 & 0.158 & & & & & 1.0 \\
\hline ANU 11276 & & & & 0.054 & 0.535 & 0.395 & 0.016 & & & & 1.0 \\
\hline Wk-20380 & & & & & 0.016 & 0.971 & 0.013 & & & & 1.0 \\
\hline ANU 11274 & & & & & & 0.004 & 0.968 & 0.028 & & & 1.0 \\
\hline ANU 11275 & & & & & & & & & 0.973 & 0.027 & 1.0 \\
\hline Joint probability & $\begin{array}{r}0.001 \\
(1)\end{array}$ & $\begin{array}{r}0.273 \\
(2)\end{array}$ & $\begin{array}{r}0.718 \\
(3)\end{array}$ & $\begin{array}{r}0.190 \\
(4)\end{array}$ & $\begin{array}{r}0.865 \\
(5)\end{array}$ & $\begin{array}{r}0.985 \\
(6)\end{array}$ & $\begin{array}{r}0.969 \\
(7)\end{array}$ & $\begin{array}{r}0.028 \\
(8)\end{array}$ & $\begin{array}{r}0.973 \\
(9)\end{array}$ & $\begin{array}{r}0.027 \\
(10)\end{array}$ & - \\
\hline
\end{tabular}

(1) 1-(1-0.001). (2) 1-(1-0.273). (3) 1-((1-0.718)"(1-0.001)). (4) 1-((1-0.008)"(1-0.137)" "(1-0.054)). (5) 1-((1-0.704)"(1$0.535) "(1-0.016)) .(6) 1-((1-0.158) "(1-0.395) "(1-0.971) "(1-0.004)) .(7) 1-((1-0.016) "(1-0.013) "(1-0.968)) .(8) 1-(1-0.028)$. (9) $1-(1-0.973) .(10) 1-(1-0.027)$.

Source: Authors' analysis.

Figure 8.2 presents a graphical view of the Mallawa example, using the $95.4 \%$ (two standard error) probability curves generated using Bronk Ramsey (2013). These curves do not cover the $100 \%$ probabilities captured in Table 8.1 , and so the chronological ranges they cover are narrower (compare, for instance, the Wk-20380 results in Figure 8.2 and Table 8.1), but they are still useful for illustrating the computation procedure. Now, the 500-year period between 2500 and 2000 BP covers the entire $95.4 \%$ probability (in fact, $97.1 \%$ ) for the Wk-20380 determination, but there are three other determinations (P3G-06 (second), ANU 11276, ANU 11274) whose true calendrical date may also fall between 2500-2000 BP. Do these other determinations substantially increase the probability, compared with relying just on Wk-20380, for occupation at Mallawa during 2500-2000 BP? Simply summing the probabilities for the four determinations (Table 8.1 ) would produce a probability greater than $100 \%$, which 
is a mathematical impossibility. Instead, following the statistically correct method outlined above, we find that the four determinations together do indeed produce a somewhat greater probability (98.5\%) of Mallawa's occupation during 2500-2000 BP compared with just relying on Wk-20380 on its own.
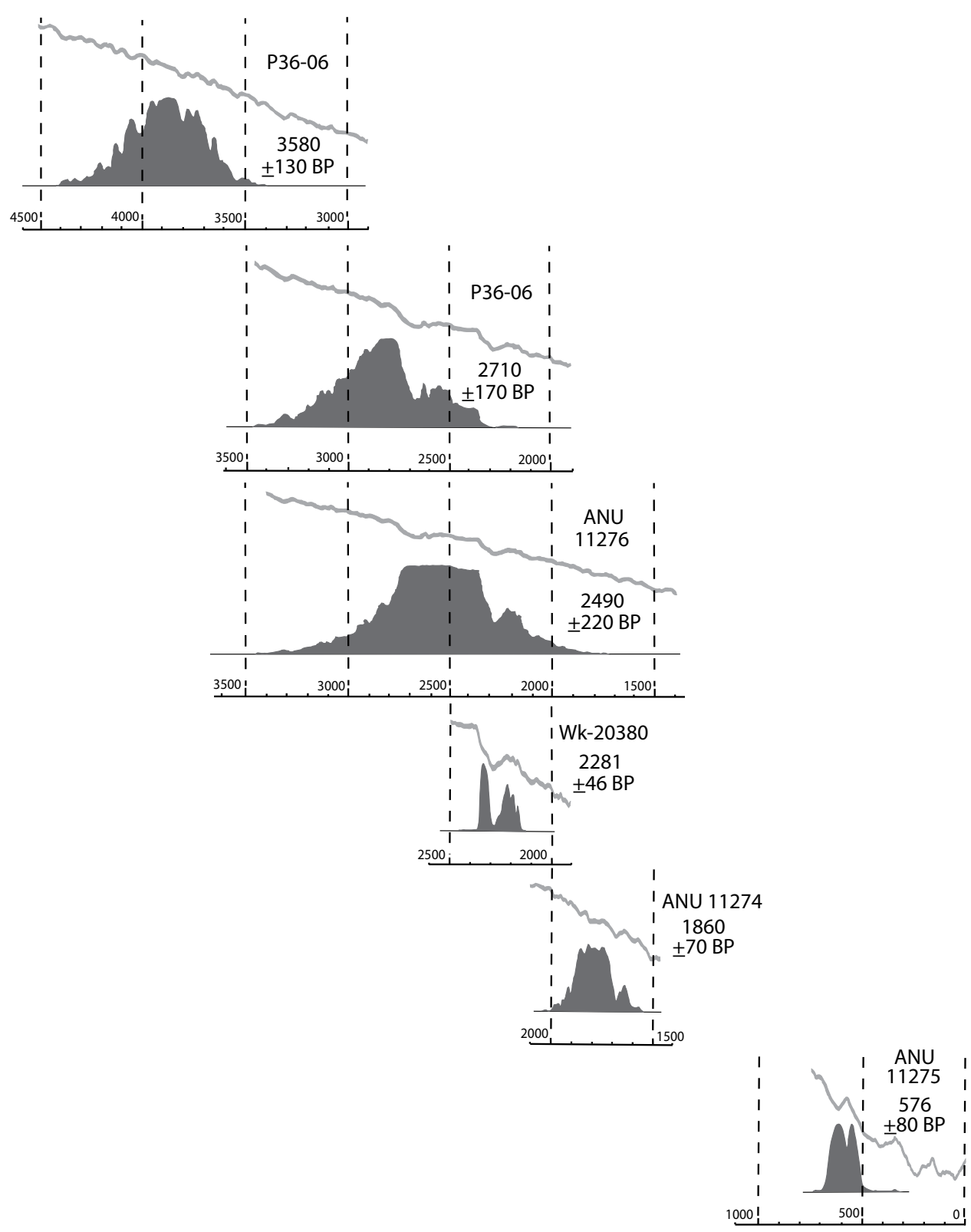

Probability of site occupancy

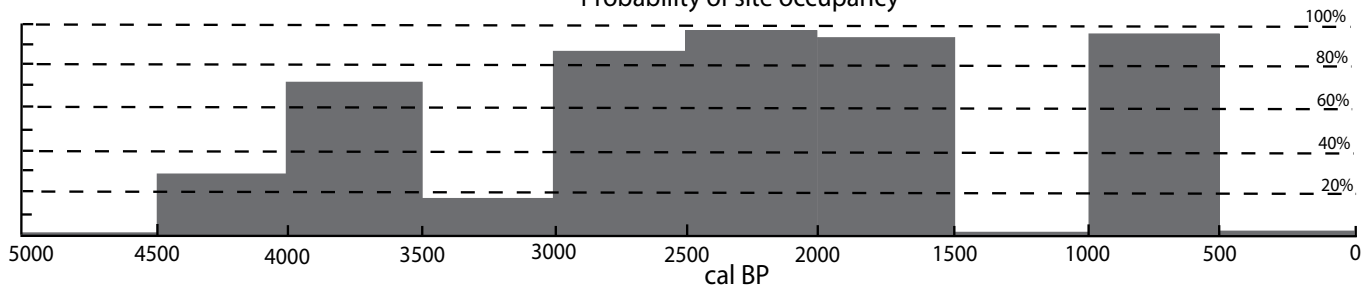

Figure 8.2: Mallawa radiocarbon dates' 95.4\% probability distributions and related calibration curves related to the probability of site occupancy by 500 -year cal BP intervals.

Sources: Bronk Ramsey (2013) output histograms (redrawn); Table 8.1. 
Figure 8.2 illustrates an additional benefit of using 500-year intervals compared with attempting to generate granular curves of radiometric dating incidences (as done by Peros et al. (2010) and Williams (2012)). The peaks and troughs in the radiocarbon calibration curve often fall comfortably inside a 500-year interval, and so have minimal impact on the probability that a determination would relate to a given interval compared with the adjacent intervals. For instance, the trough at around $2300 \mathrm{BP}$ is clearly reflected in bimodal calibration curves for ANU 11276 and Wk-20380 during the 2500-2000 BP interval (Figure 8.2), but the two modes are aggregated when the probability of 2500-2000 BP occupation at Mallawa is calculated (Table 8.1). Accordingly, the risk is neutralised of producing apparent patterns of occupation intensity that are a product of the radiocarbon calibration curve (as discussed by Bamforth and Grund 2012), and any need to accommodate for this effect is minimised.

The 73 sites with accepted determinations are independent entities, and so their joint probabilities of occupancy by half-millennium can be summed to estimate the probable number of Sulawesi sites occupied for each half-millennium. Take the example of four sites each with a 0.25 probability of occupancy during a given half-millennium, producing a summed probability of one occupied site. In reality, the number of occupied sites could be between zero and four, with the following probabilities:

0 sites: $1 *(0.75 * 0.75 * 0.75 * 0.75)=0.316$

1 site: $4^{*}\left(0.25^{*} 0.75 * 0.75 * 0.75\right)=0.422$

2 sites: $6^{*}\left(0.25^{*} 0.25^{*} 0.75 * 0.75\right)=0.211$

3 sites: $4 *(0.25 * 0.25 * 0.25 * 0.75)=0.047$

4 sites: $1 *\left(0.25^{*} 0.25^{*} 0.25^{*} 0.25\right)=0.004$

The modal probability is one occupied site. Also, while there is a greater probability of zero than two-four occupied sites, this is offset by the possibility of several sites more than 1 occupied site as represented by the probabilities for three and for four occupied sites.

The procedure outlined above can also be undertaken as separate exercises for the site aspect categories, site usage categories and dated material classes (see Results).

Because the site occupancy levels are modest in scale, reaching a maximum of 33 occupied sites for any 500-year interval (see below), no attempt is made to formally correct the calculated site numbers for potential biases such as site taphonomic loss. Instead, these potential biases will be considered at an intuitive level in the Discussion.

\section{Results}

The clearest introductory overview of Sulawesi Holocene site occupancy is provided by considering site aspect. All of the sites have a single aspect except for the large Tinco Tua site (Kallupa et al. 1989), which has 'Monumental' and 'Open' aspects (Table A8.6), computed separately. Also, in view of the hierarchy of site aspect categories, the two overarching aspects are closed sites and open-air sites (covering all sites that are not closed).

The site aspect graph (Figure 8.3) shows continuous use of closed sites in Sulawesi covering the last 10,000 years BP, including a mid-Holocene spike for the 4500-3500 BP period, followed by a second, more pronounced spike after $2000 \mathrm{BP}$. This second spike predominantly reflects the use of closed sites for depositing human remains over the last couple of millennia BP, as will become evident when the site usage categories are considered. 


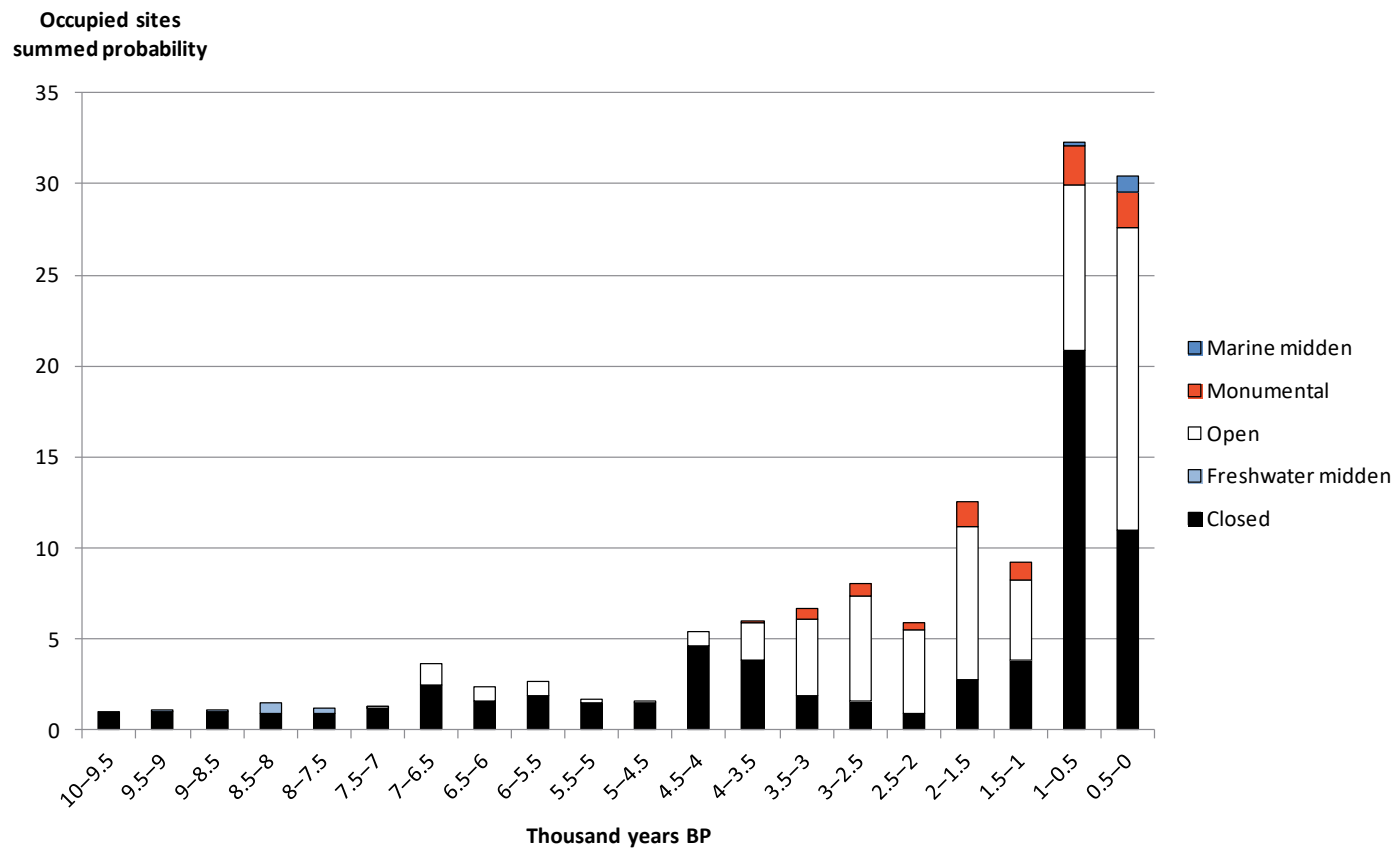

Figure 8.3: Sulawesi sites summed probabilities by site aspect.

Source: Author's data.

Shell middens make just a miniscule contribution to Sulawesi's archaeological chronometry, even though the Paso freshwater shell midden (3 in Figure 8.1) is the oldest open-air site in Sulawesi. The single dated marine shell midden, named Salabu (25 in Figure 8.1), has a very high probability of dating to the $<500$ years BP interval. 'Open' sites make a detectable contribution to Sulawesi site occupancy levels during the 7000-5500 BP interval and then with increasing impact from $4500 \mathrm{BP}$ onwards. They are joined by 'Monumental' (megalithic) sites from $2500 \mathrm{BP}$ onwards, present with sufficient regularity to propose $2500 \mathrm{BP}$ as an approximate inception date for Sulawesi's widespread megalithic tradition(s).

When site usage is considered, we see that the 'Habitation' category accounts for all of the radiometric determinations up to $3500 \mathrm{BP}$, and the great majority of radiometric determinations till as recently as $2500 \mathrm{BP}$ (Figure 8.4). The 'Ceremonial' category (notably for open-air sites) is consistently represented for the period between approximately $3000 \mathrm{BP}$ and the present, along with the 'Mortuary' category (for both closed and open-air sites) after 2500 BP. The late Holocene dating for these site usage categories reflects the availability of accepted radiometric determinations rather than the limitations of Sulawesi's early to middle Holocene inhabitants for a symbolic capacity. Uranium-series dates obtained for parietal paintings in the Maros karsts document an age range of c. 40,000-18,000 years BP for a symbolic propensity in Sulawesi Homo sapiens; unfortunately, direct dates are yet to be published for the very large body of Sulawesi rock paintings that are not covered by the collaroid speleothems that allowed the above-mentioned late Pleistocene dates to be obtained (Oktaviana et al. 2016). Similarly, the mid-Holocene date for a burial from Leang Burung 1 (ANU 6175 in Table A8.1) is fully consistent with the burial's preceramic stratigraphic context, but the determination was obtained from the human bone apatite fraction and so is sadly not reliable enough for inclusion in the present study. 


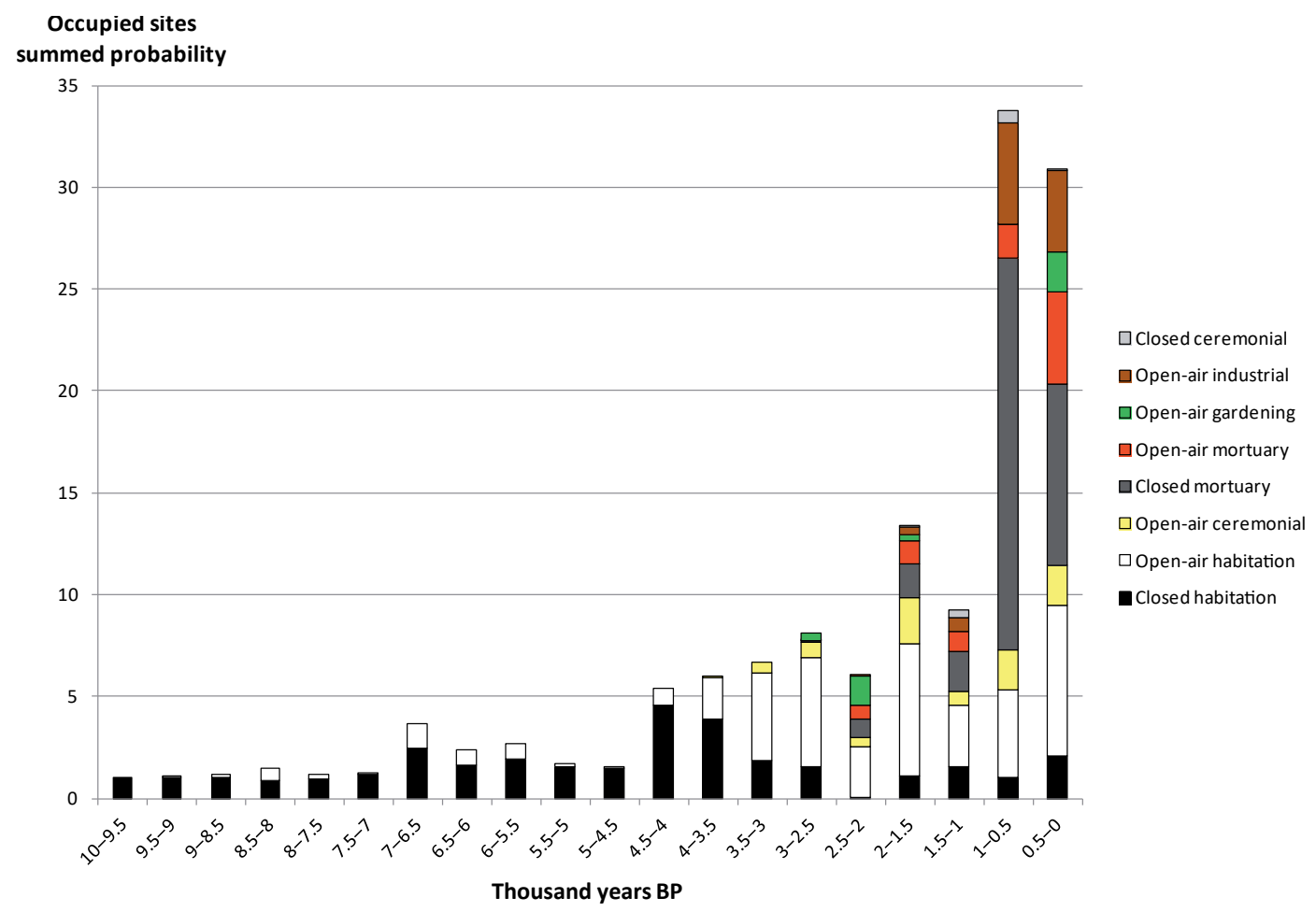

Figure 8.4: Sulawesi sites summed probabilities by site usage.

Source: Author's data.

However, there are two examples of site usage categories whose late Holocene representation is more reasonably taken at face value. One is the 'Gardening' category, convincingly documented for 2500-2000 BP, which can be interpreted as a minimum estimate for when farming activities allowed the establishment of permanent kampong settlements in Sulawesi (e.g. Anggraeni et al. 2014). The second is the 'Industrial' category, in particular ironworking for which Sulawesi (sula besi = 'island of iron') received its name. The industry appears to have originated by around $1500 \mathrm{BP}$ and to have been in full operation throughout the last millennium BP (Figure 8.4).

Until approximately $2500 \mathrm{BP}$, the available radiometric determinations reflect the exclusive or predominant of closed sites for habitation rather than mortuary disposals, but this relationship switches after $2500 \mathrm{BP}$, especially during the last millennium BP when dates on mortuary disposals in closed sites make up the single largest site usage category.

The graph for dating material (Figure 8.5) shows the exclusive reliance on charcoal both for closed and open-air sites until c. 5000 BP. Animal matter as a dating material appeared in closed sites during the 5th millennium BP and in open-air sites from around $3500 \mathrm{BP}$ to the present. The ceramic category is convincingly represented in open-air sites during 3000-2500 BP and in open-air and closed sites (in combination) during 2000-500 BP. This is direct evidence for a minimum date of $3000 \mathrm{BP}$ for the appearance of pottery in Sulawesi. 


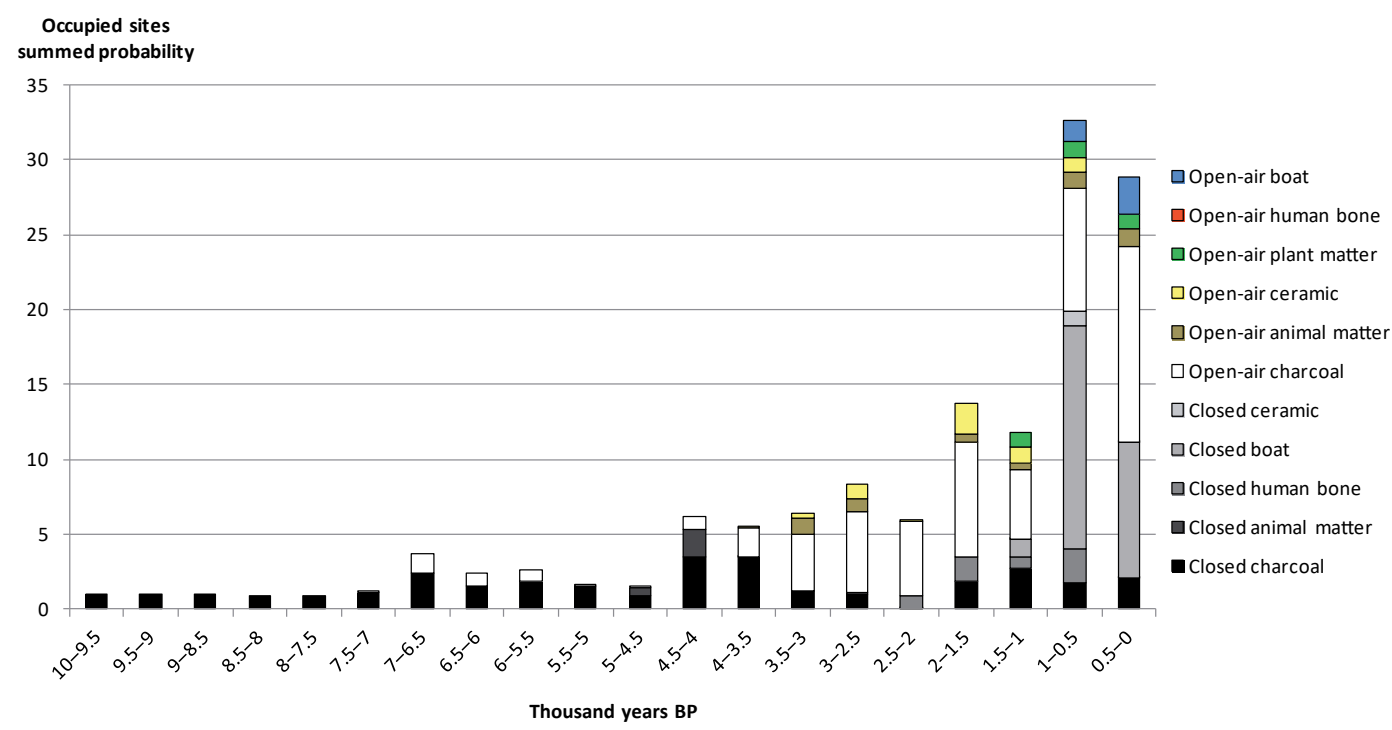

Figure 8.5: Sulawesi sites summed probabilities by dating material.

Source: Author's data.

The three dating materials restricted to the last 2000 years BP on current documentation are the 'Human bone', 'Plant matter' and 'Boat' categories. The boat category, constituted by dates on boat-shaped coffins, is represented at a modest number of closed sites for the 1500-1000 BP interval and then a large number of closed sites and moderate number of open-air sites for the last millennium BP. These boat dates are maximum estimates of antiquity because the samples generally derive from the bark and/or outer tree-rings, and so more closely reflect the date when the tree was a sapling rather than when it was felled for making into a coffin. For instance, in his discussion of the dates from the Enrekang coffins (47-52 in Figure 8.1), Duli (2013) noted that the dates on Elmerillia celebica (Dandy) wood were systematically several centuries older than the dates on Vitex cofassus (Reinwald) wood, and so proposed that the c. 600 to $700 \mathrm{cal}$ BP dates on E. celebica wood should be interpreted as maximally 500 to $550 \mathrm{cal} \mathrm{BP}$ in terms of the Enrekang coffins' age.

Accordingly, although it is not possible to formally accommodate the 'old wood effect' impacting on the boat-shaped coffins' age, it is fully possible that all of these coffins would correctly date to the last millennium BP, and that the number of them that are $\angle 500 \mathrm{BP}$ in age is at least equal to the number with a true antiquity of 1000-500 BP. The implied effects on the overall pattern of site occupancy over time would be to increase the degree to which the 1500-1000 BP interval is less well represented than the 2000-1500 BP interval, but also to even up the 1000-500 BP and 500-0 BP histogram heights.

\section{Discussion}

Taphonomic effects may have had some impact on the results. For instance, the slightly lower site occupancy recorded between 10,000-7000 BP compared with 7000-4500 BP, and the fact that the only open-air site for the former period is a freshwater shell midden, may reflect greater taphonomic loss or burial of early Holocene sites. Also, the greater variability of late Holocene dating materials compared with early to mid-Holocene materials may partly reflect disintegration of older samples to the status of 'Charcoal', although two of the late Holocene material categories (the 'Ceramic' and 'Boat' categories) would appear to reflect late Holocene technological 
innovations. Overall, a generally increased visibility of open-air sites between the 4500-4000 and 500-0 BP intervals (Figure 8.3) would have had some impact on site occupancy levels, even if difficult to quantify.

On the other hand, any impact of calibration effects would be debatable. For instance, these effects should exaggerate the 2500-2000 BP occupancy level compared with 3000-2500 BP (Williams 2012:582), but the results actually suggest a slight dip during 2500-2000 BP. As observed in the earlier discussion for Figure 8.2, late Holocene dips and troughs in the calibration curve appear to be accommodated by this study's 500 -year BP intervals and, as for the early Holocene, site numbers by 500 -year interval are uniformly small.

Overall, the proposition by Brandão et al. (2016) of a 70-fold population increase in ISEA commencing at around 4000 years ago appears to be broadly confirmed by the sustained increase in Sulawesi site occupancy levels documented to have begun at around 4500 BP. Yet the interpretation is complicated by the observation that the increased site occupancy levels initially spiked for closed habitation sites, but these levels declined after 4000 BP as occupancy levels of open-air sites and closed mortuary sites came to the fore (Figure 8.4). This increased occupancy of sites other than closed habitation sites may be a more fitting counterpart to the population increase posited by Brandáo et al. (2016).

The transition from mainly closed habitation sites to mainly open-air sites between 4500 and $2000 \mathrm{BP}$, during a period when overall site occupancy levels appear to have remained stable, is intriguing but difficult to explain. Explanation is difficult because the sites concerned are located in mutually exclusive areas. The critical closed sites are located in South and Southeast Sulawesi (specifically, 54-56, 62-65 and 72 in Figure 8.1), compared with the critical open-air sites in North and West Sulawesi plus a single South Sulawesi site (Mallawa, lying to the north of the South Sulawesi closed habitation sites). A simplistic explanation would entertain a desertion of the closed sites whose former occupants migrated to the locations where open-air sites have been documented. But the distances involved are large, and most authorities today would link the growth of open-air sites to the incursion of Austronesian speakers from the Philippines (e.g. Simanjuntak 2008; Anggraeni et al. 2014). In addition, even if the increase in open-air sites after $3500 \mathrm{BP}$ can be linked to the greater visibility of Austronesian settlements compared with pre-Austronesian forager campsites, this would not explain the apparent decline in closed habitation sites after $4000 \mathrm{BP}$.

Accordingly, it may seem more reasonable to propose that the Malayo-Polynesian (Austronesian) incursion led to disturbances to the environment or transformations of the social landscape that diminished the attractiveness of habitation of closed sites. However, to test this proposition, relevant data would be required from open-air sites in the locations where we have the closed sites and closed sites where we have the open-air sites. This may be a strategic priority for future research on Sulawesi's late Holocene archaeology, which may also test whether the currently recorded 4500-4000 BP peak in closed habitation sites (Figure 8.4) is an artefact of sampling or a firm result to be reckoned with.

The author's proposition of a population increase with the advent of the Early Metal Phase at around 2000 BP, based on my review of the archaeological evidence from South and West Sulawesi (Bulbeck 2010), is confirmed for Sulawesi generally in terms of site occupancy levels. Documented occupancy levels were higher throughout the 2nd millennium BP than at any earlier stage. Also, the site usage categories were variable, including the evident addition of local industrial (ironworking) sites at some point during the millennium. However, there is no sign of increased site occupancy levels during the millennium, whether or not we literally interpret the apparent dip in these levels during the 1500-1000 BP interval compared with the 2000-1500 BP interval. 
The author's proposition of a population increase at around 750 BP (Bulbeck 2010) is also confirmed by the high site occupancy levels, in excess of 30 per 500-year interval, throughout the 1st millennium BP. In this case, the majority of the avalanche of site dates were obtained through projects that aimed to elucidate the early history of specific ethnographic-cum-historical situations as recorded for South Sulawesi: Bulbeck's (1992) study of the origins of the Macassar empire; Bulbeck and Caldwell's (2000) investigation into the origins of ironworking associated with the rise of the Bugis kingdom of Luwu; and the projects by Duli $(2012,2013)$ to date the coffins stored in caves by the Tana Toraja and Enrekang ethnic groups. This point raises the possibility that the observed leap in site occupancy levels reflects a c. 1000-year time depth for most of the archaeological sites that can be encountered from following up on ethnohistorical reports (oral and/or written).

However, it is also the case that most of South Sulawesi and the lowland stretches of West Sulawesi were well populated as of c. 500 BP (e.g. Andaya 1981), and in the case of Macassar and its immediate hinterland, the number of archaeological sites combined with historical records suggests a population increase from around 60,000 people in the 14 th century AD to 170,000 in the 17th century AD (Bulbeck 1992). The urban and dense rural populations recorded for much of southwestern Sulawesi at this time reflects the combination of widespread wet-rice agriculture, cultivation of numerous ancillary crops on generally fertile soils and intensive trade (Bulbeck 1992; Bulbeck et al., this volume), which may not have applied generally across Sulawesi. The significant number of Indian cotton patola traded to Central Sulawesi, with AMS dates of c. $600 \mathrm{BP}$ and later (Table A8.1), possibly suggests similar developments there to those documented for southwestern Sulawesi; unfortunately, these patola lack any archaeological context. In short, the documented peak in site occupancy levels during the last millennium BP relates specifically to South Sulawesi, and the extent to which it could be generalised across Sulawesi would be a matter for future research.

One topic for discussion is the impact of radiometric determinations that fall outside of the main concentration of dates, which can be addressed by considering these determinations for the Minanga Sipakko and Kamassi sites (9 and 10 in Figure 8.1). At both sites, multiple dates refer to the 3500-2500 BP 'Neolithic' period, resulting in a probability of occupancy of $100 \%$ for 3500-3000 BP and over 75\% for 3000-2500 BP. However, the accepted determinations also point to probable earlier occupancy, as early as 7000-6500 BP (80\% probability for Kamassi), 4500-4000 BP (56\% probability for Minanga Sipakko) and 4000-3500 BP (100\% probability for Minanga Sipakko). No suggestion is being made here that the Neolithic in Sulawesi necessarily dates to earlier than $3500 \mathrm{BP}$; instead, that the excavation of these sites recovered evidence for pre-Neolithic occupancy at riverside locations ideal for habitation. ${ }^{1}$

The Kamassi site contributes to the intriguing suggestion of a minor, isolated peak in occupancy levels of open sites (and therefore sites overall) between 7000-5500 BP (Figure 8.3). But the apparent 5500-4500 BP dip probably reflects sampling error, as suggested by the significant number of 'Maros points' recorded as surface finds in Southwest Sulawesi. A Toalean type (see footnote 1), these hollow-based, denticulated projectile points are dated from closed sites to 5000-3500 BP (Bulbeck 2004). Accordingly, if they could be dated, the open sites with Maros points may counteract any 5500-4500 BP dip in occupancy levels. A case in point is Pammangkulang Batua, on the bank of a major river (the Je'ne'berang, just south of the Lamuru site; 67 in Figure 8.1), where 422 stone artefacts including two Maros points were collected. Unfortunately, the site would be unsuitable for excavation, not only because the stone artefacts'

1 The decision by Anggraeni et al. (2014) to reject these early dates, based on the lack of 'Toalean' tool types in the excavated deposits, is without foundation, because the Toalean was restricted to the Southwest Sulawesi peninsula, as documented by Bulbeck (2004:154; see also the papers in this volume by Hasanuddin and by O'Connor et al.). 
original context was apparently a thin soil covering the local conglomerates, but also because they were subsequently disturbed to the surface through quarrying of the site's conglomerates (Pasqua 1995).

In general, the recovery of open-air pre-Neolithic sites in stratified context is a confronting task for archaeologists in the face of the 'twin taphonomic terrors' of wholesale erosion of the site or its burial deep beneath overburden deposit. Certainly, pre-Neolithic open habitation are drastically under-represented by their small number of available dates, even after acceptance of the examples from Minanga Sipakko and Kamassi.

\section{Conclusion}

The radiometric dates from Sulawesi sites accepted for this study suggest persistent but low levels of site occupancy between 10,000 and $4500 \mathrm{BP}$, followed by dynamic change during the late Holocene. Site occupancy levels stepped up during the 4500-2000 BP period, and again during the 2000-1000 and 1000-0 BP periods. Habitation occupancy of closed sites peaked during the 4500-4000 BP interval, but declined in later times as the occupancy of open-air sites for habitation and other purposes, and (after $2000 \mathrm{BP}$ ) the use of closed sites for mortuary purposes, became increasingly evident. Dating material analysis indicates a minimum age of $3000 \mathrm{BP}$ for the presence of ceramics in Sulawesi, while site aspect analysis and site usage analysis suggest a minimum age of $2500 \mathrm{BP}$ for gardening activities and the inception of megalithic practices in Sulawesi, respectively. Other important developments in Sulawesi for which dating evidence is available include ironworking by $1500 \mathrm{BP}$ and the production of boat-shaped coffins (after allowing for the potential 'old wood effect' in these coffins) by 1000 BP.

Remembering that the synopsis presented here is based on just 73 sites, and that the accepted dates include many that were obtained before AMS dating became standard practice, we should treat the results of this study as a hypothesis for future testing as archaeological outreach across Sulawesi is extended and the recovery of strongly rigorous radiometric determinations becomes more entrenched.

\section{Acknowledgements}

The author thanks two anonymous referees for their valuable comments on the originally submitted version of this manuscript.

\section{Author biography}

David Bulbeck Department of Archaeology and Natural History, School of Culture, History and Language, College of Asia and the Pacific, The Australian National University, Canberra, Australia

\section{References}

Andaya, L.Y. 1981. The Heritage of Arung Palakka: A History of South Sulawesi (Celebes) in the Seventeenth Century. Verhandelingen van het Koninklijk Instituut voor Taal-, Land- en Volkenkunde 91. The Hague: Martinus Nijhoff. 
Anggraeni. 2012. The Austronesian Migration Hypothesis as seen from Prehistoric Settlements on the Karama River, Mamuju, West Sulawesi. Unpublished PhD thesis, School of Archaeology and Anthropology, The Australian National University, Canberra.

Anggraeni. 2016. The development of Neolithic-Palaeometallic pottery with a special reference to the Karama Valley, West Sulawesi. Presentation at 'The Archaeology of Sulawesi - An Update', Makassar, Sulawesi, 31 January - 2 February.

Anggraeni, T. Simanjuntak, P. Bellwood and P. Piper. 2014. Neolithic foundations in the Karama valley, West Sulawesi, Indonesia. Antiquity 88(341):740-756. doi.org/10.1017/S0003598X00050663 (accessed 5 June 2018).

Azis, N., C. Reepmeyer, G. Clark, Sriwigati and D.A. Tanudirjo. 2018. Mansiri in North Sulawesi: A new dentate-stamped pottery site in Island Southeast Asia. In S. O'Connor, D. Bulbeck and J. Meyer (eds), The Archaeology of Sulawesi: Current Research on the Pleistocene to the Historic Period, pp. 191-206. Canberra: ANU Press.

Bamforth, D.B. and B. Grund. 2012. Radiocarbon calibration curves, summed probability distributions, and early Paleoindian population trends in North America. Journal of Archaeological Science 39(6):1768-1774. doi.org/10.1016/j.jas.2012.01.017 (accessed 5 June 2018).

Barnes, R. and M.H. Kahlenberg (eds). 2010. Five Centuries of Indonesian Textiles: The Mary Hunt Kahlenberg Collection. Munich: Delmonico Books.

Bellwood, P. 1976. Archaeological research in Minahasa and the Talaud Islands, Northeastern Indonesia. Asian Perspectives 19(2):240-288.

Brandão, A., K.K. Eng, T. Rito, B. Cavadas, D. Bulbeck, F. Gandini, M. Pala, M. Mormina, B. Hudson, J. White, T.-M. Ko, M. Saidin, Z. Zafarina, S. Oppenheimer, M.B. Richards, L. Pereira and P. Soares. 2016. Quantifying the legacy of the Chinese Neolithic on the maternal genetic heritage of Taiwan and Island Southeast Asia. Human Genetics 135(4):363-376. doi.org/10.1007/s00439-016-1640-3 (accessed 5 June 2018).

Bronk Ramsey, C. 2013. OxCal 4.2 manual. RC.arch.ox.ac.uk/oxcal/Oxcal.html (accessed 3 November 2016).

Bronson, B. and I. Glover. 1984. Archaeological radiocarbon dates from Indonesia: A first list. Indonesia Circle 12(34):37-44. doi.org/10.1080/03062848408729585 (accessed 5 June 2018).

Bulbeck, F.D. 1992. A Tale of Two Kingdoms: The Historical Archaeology of Gowa and Tallok, South Sulawesi, Indonesia. Unpublished PhD thesis, School of Archaeology and Anthropology, The Australian National University, Canberra. www.oxis.org/theses/bulbeck-1992.pdf (accessed 5 June 2018).

Bulbeck, D. 2004. Divided in space, united in time: The Holocene prehistory of South Sulawesi. In S.G. Keates and J.M. Pasveer (eds), Quaternary Research in Indonesia, pp. 129-166. Modern Quaternary Research in Southeast Asia, Volume 18. Leiden: A.A. Balkema.

Bulbeck, D. 2010. Uneven development in Southwest Sulawesi, Indonesia during the Early Metal Phase. In B. Bellina, E.A. Bacus, T.O. Pryce and J.W. Christie (eds), 50 Years of Archaeology in Southeast Asia: Essays in Honour of Ian Glover, pp. 153-169. Bangkok: River Books.

Bulbeck, D. 2014. The chronometric Holocene archaeological record of the southern Thai-Malay Peninsula. International Journal of Asia Pacific Studies 10(1):112-162.

Bulbeck, D. 2016. The Neolithic Gap in the Southern Thai-Malay Peninsula and its implications for Orang Asli prehistory. In K. Endicott (ed.), Malaysia's Original People: Past, Present and Future of the Orang Asli, pp. 123-152. Singapore: NUS Press. 
Bulbeck, D., F.A. Aziz, S. O’Connor, A. Calo, J.N. Fenner, B. Marwick, J. Feathers, R. Wood and D. Prastiningtyas. 2016. Mortuary caves and the dammar trade in the Towuti-Routa region, Sulawesi, in an Island Southeast Asian context. Asian Perspectives 55(2):148-183. doi.org/10.1353/asi.2016.0017 (accessed 5 June 2018).

Bulbeck, D. and I. Caldwell. 2000. Land of Iron: The Historical Archaeology of Luwu and the Cenrana Valley. Results of the Origin of Complex Society in South Sulawesi Project (OXIS). Hull: Centre for South-East Asian Studies, University of Hull. www.oxis.org/books/land-of-iron.pdf (accessed 5 June 2018).

Bulbeck, D. and I. Caldwell. 2008. Oryza sativa and the origins of kingdoms in South Sulawesi, Indonesia: Evidence from rice husk phytoliths. Indonesia and the Malay World 36(104):1-20. doi.org/10.1080/ 13639810802016117 (accessed 5 June 2018).

Bulbeck, D., I. Caldwell, S. Druce, B. Hakim and C. Macknight. 2018. Imported tradeware ceramics and their relevance for dating socio-political developments in South Sulawesi, with special reference to the Allangkanangnge ri Latanete site. In S. O'Connor, D. Bulbeck and J. Meyer (eds), The Archaeology of Sulawesi: Current Research on the Pleistocene to the Historic Period, pp. 269-286. Canberra: ANU Press.

Bulbeck, D. and M.A. Fadillah. 2000. The context of the carnelian beads from Bonto-Bontoa, Bantaeng, South Sulawesi. Walennae 3(1):44-48.

Bulbeck, D. and B. Hakim. 2005. The human fossil cranium from Leang Batu Tunpa, Selayar, Sulawesi Selatan. In D.W. Utomo, Hasanuddin, B. Hakim and A.F. Uma (eds), Menguak Tabir Kehidupan Masa lalu dan kini, pp. 71-84. Makassar: Balai Arkeologi Makassar.

Bulbeck, D. and Nasruddin. 2002. Recent insights on the chronology and ceramics of the Kalumpang site complex, South Sulawesi, Indonesia. Bulletin of The Indo-Pacific Prehistory Association 22:83-100.

Bulbeck, D., M. Pasqua and A. Di Lello. 2000. Culture history of the Toalean of South Sulawesi, Indonesia. Asian Perspectives 39(1-2):71-108. doi.org/10.1353/asi.2000.0004.

Downey, S.S., E. Bocaege, T. Kerig, K. Edinborough and S. Shennan. 2014. The neolithic demographic transition in Europe: Correlation with juvenility index supports interpretation of the summed calibrated radiocarbon date probability distribution (SCDPD) as a valid demographic proxy. PLoS ONE 9(8):e105730. doi.org/10.1371/journal.pone.0105730 (accessed 5 June 2018).

Druce, S., D. Bulbeck and I. Mahmud. 2005. A transitional Islamic Bugis cremation in Bulubangi, South Sulawesi: Its historical and archaeological context. Review of Indonesian and Malaysian Affairs 39(1):1-22.

Duli, A. 2012. Budaya Keranda Erang di Tana Toraja. Unpublished PhD thesis, Centre for Archaeological Research Malaysia, Universiti Sains Malaysia, Kuala Lumpur.

Duli, A. 2013. The mandu coffin: A boat symbol of ancestral spirits among the Enrekang people of South Sulawesi. Review of Indonesian and Malaysian Affairs 47(1):115-138.

Fakhri. 2016. Situs Rampi: Masa persebaran arca batu dan hubungannya dengan di wilayah situs terdekat (Rampi sites: The dispersion age of stone statue and the connection between nearest site areas). Walennae 14(1):23-36. walennae.kemdikbud.go.id/index.php/walennae/article/view/38 (accessed 27 October 2018).

Fakhri. 2018. Vertebrate fauna from Gua Sambangoala, Southeast Sulawesi. In S. O'Connor, D. Bulbeck and J. Meyer (eds), The Archaeology of Sulawesi: Current Research on the Pleistocene to the Historic Period, pp. 153-170. Canberra: ANU Press.

Fakhri, Suryatman, B. Hakim and R. Sardi. 2015. Exploration of prehistoric sites in the Karama watershed, West Sulawesi, Indonesia. Journal of Indo-Pacific Archaeology 39:18-25. journals.lib.washington.edu/ index.php/JIPA/article/view/14786/12489 (accessed 5 June 2018). 
Glover, I. 1978. Survey and excavation in the Maros district, south Sulawesi, Indonesia: The 1975 field season. Bulletin of The Indo-Pacific Prehistory Association 1:60-103.

Glover, I.C. 1981. Leang Burung 2: An upper Palaeolithic rock shelter in South Sulawesi, Indonesia. In G.-J. Bartstra and W.A. Casparie (eds), Modern Quaternary Research in Southeast Asia, pp. 1-38. Modern Quaternary Research in Southeast Asia, Volume 6. Rotterdam: A.A. Balkema.

Glover, I. 1997. Southeast Asia. In S. Hooper (ed.), Robert and Lisa Sainsbury Collection, pp. 214-217. Ipswich: University of East Anglia.

Guy, J. 1998. Woven Cargoes: Indian Textiles in the East. London: Thames and Hudson.

Hakim, B., M. Nur and Rustam. 2009. The sites of Gua Pasaung (Rammang-Rammang) and Mallawa: Indicators of cultural contact between the Toalian and Neolithic complexes in South Sulawesi. Bulletin of The Indo-Pacific Prehistory Association 29:45-52. doi.org/10.7152/bippa.v29i0.9476 (accessed 5 June 2018).

Hasanuddin. 2015. Kebudayaan Megalitik di Sulawesi Selatan dan Hubungannya dengan Asia Tenggara. Unpublished PhD thesis, Centre for Archaeological Research Malaysia, Universiti Sains Malaysia, Kuala Lumpur. www.oxis.org/theses/hasanuddin-2015.pdf (accessed 5 June 2018).

Hasanuddin. 2018. Prehistoric sites in Enrekang Kabupaten, South Sulawesi. In S. O'Connor, D. Bulbeck and J. Meyer (eds), The Archaeology of Sulawesi: Current Research on the Pleistocene to the Historic Period, pp. 171-190. Canberra: ANU Press.

Higham, T., C. Bronk Ramsey, F. Brock, D. Baker and P. Ditchfield. 2007. Radiocarbon dates from the Oxford AMS system: Archaeometry datelist 32. Archaeometry 49(Supplement s1):S1-S60. doi.org/ 10.1111/j.1475-4754.2007.00363.x (accessed 5 June 2018).

Hiscock, P. and V. Attenbrow. 2016. Dates and demography? The need for caution in using radiometric dates as a robust proxy for prehistoric population change. Archaeology in Oceania 51(3):218-219. doi.org/10.1002/arco.5096 (accessed 5 June 2018).

Kallupa, B., D. Bulbeck, I. Caldwell, I. Sumantri and K. Demmanari. 1989. Survey Pusat Kerajaan Soppeng 1100-1986 [Survey of the Capital of Soppeng Kingdom 1100-1980. Final Report to the Australian Myer Foundation, Privately published in Canberra, ACT. www.oxis.org/books/soppeng-1986.pdf (accessed 5 June 2018).

Kirleis, W., J. Müller, C. Kortemeier, H. Behling and S. Soeghondo. 2012. The megalithic landscape of Central Sulawesi, Indonesia: combining archaeological and palynological investigations. In M.L. Tjoa-Bonatz, A. Reinecke and D. Bonatz (eds), Crossing Borders in Southeast Asian Archaeology: Selected Papers from the 13th International Conference of the European Association of Southeast Asian Archaeologists, Berlin, 2010, pp. 199-220. Singapore: NUS Press.

O’Connor, S., F.A. Aziz, B. Marwick, J. Fenner, B. Prasetyo, D. Bulbeck, T. Maloney, E.S. Pierre, R. Whitau, U.P. Wibowo, B. Hakim, A. Calo, Fakhri, M. Husni, Hasanuddin, A.A. Oktaviana, D. Prastiningtyas, F.Z. Campos, and P.J. Piper with an appendix by A.A. Oktaviana and Suryatman. 2014. The Archaeology of Sulawesi: A Strategic Island for Understanding Modern Human Colonization and Interactions Across our Region. Final Report to Indonesia's Bureau of Research and Technology, Department of Archaeology and Natural History, The Australian National University, Canberra and Department of Prehistory, Indonesia's National Centre for Archaeological Research and Development, Jakarta.

O’Connor, S., D. Bulbeck, P.J. Piper, F. Aziz, B. Marwick, F. Campos, J. Fenner, K. Aplin, Fakhri, Suryatman, T. Maloney, B. Hakim and R. Wood. 2018. The human occupation record of Gua Mo'o hono shelter, Towuti-Routa region of Southeastern Sulawesi. In S. O'Connor, D. Bulbeck and J. Meyer (eds), The Archaeology of Sulawesi: Current Research on the Pleistocene to the Historic Period, pp. 117152. Canberra: ANU Press. 
Oktaviana, A.A., D. Bulbeck, S. O’Connor, B. Hakim, Suryatman, U.P. Wibowo, E. St Pierre and Fakhri. 2016. Hand stencils with and without narrowed fingers at two new rock art sites in Sulawesi, Indonesia. Rock Art Research 33(1):32-48.

Pasqua, M. 1995. Mid-Late Holocene Toalean Sites in South Sulawesi: A Technological Analysis. Unpublished BSc Honours thesis, Centre for Archaeology, University of Western Australia, Perth.

Peros, M.C., S.E. Munoz, K. Gajewski and A.E. Viau. 2010. Prehistoric demography of North America inferred from radiocarbon data. Journal of Archaeological Science 37(3):656-664. doi.org/10.1016/j/ jas.2009.10.029 (accessed 5 June 2018).

Simanjuntak, T. 2008. Austronesian in Sulawesi: Its origin, diaspora, and living tradition. In T. Simanjuntak (ed.), Austronesian in Sulawesi, pp. 215-251. Jakarta: Center for Prehistoric and Austronesian Studies.

Simanjuntak, T. 2010. Penutur dan budaya Austronesia. In N. Harkantiningsih, T. Simanjuntak and E.S. Hardiati (eds), Arkeologi Indonesia Dalam Lintasan Zaman, pp. 41-71. Jakarta: Pusat Penelitian dan Pengamban Arkeologi Nasional.

Simanjuntak, T., M.J. Morwood, F.S. Intan, I. Mahmud, K. Grant, N. Somba, B. Akw and D.W. Utomo. 2008. Minanga Sipakko and the Neolithic of the Karama River. In T. Simanjuntak (ed.), Austronesian in Sulawesi, pp. 57-75. Jakarta: Center for Prehistoric and Austronesian Studies.

Spriggs, M. 2003. Chronology of the Neolithic transition in Island Southeast Asia and the Western Pacific: A view from 2003. The Review of Archaeology 24(2):57-80.

Storm, P., R. Wood, C. Stringer, A. Bartsiokas, J. de Vos, M. Aubert, L. Kinsley and R. Grün. 2013. U-series and radiocarbon analyses of human and faunal remains from Wajak, Indonesia. Journal of Human Evolution 64(5):356-365. doi.org/10.1016/j.jhevol.2012.11.002 (accessed 5 June 2018).

Williams, A. 2012. The use of summed radiocarbon probability distributions in archaeology: A review of methods. Journal of Archaeological Science 39(3):578-589. doi.org/10.1016/j.jas.2011.07.014 (accessed 5 June 2018).

Yuniawati, D.Y. 2006. Kubur Batu Waruga di Sub-Etnis Tou'Mbulu Sulawesi Utara. Jakarta: Pusat Penelitian dan Pengembangan Arkeologi Nasional.

\section{Appendix A: Sulawesi radiometric determinations}

Table A8.1: Rejected Sulawesi Holocene radiometric determinations (oldest to youngest determinations): Radiocarbon dates unless otherwise specified.

\begin{tabular}{|c|c|c|c|c|c|}
\hline Site/ Location & Date & Dating material & Laboratory code & Reference & Reason for rejection \\
\hline Ulu Leang 2 & $8995 \pm 50 \mathrm{BP}$ & Freshwater shell & GRN-8647 & $\begin{array}{l}\text { Bronson and } \\
\text { Glover } 1984\end{array}$ & $\begin{array}{l}\text { Freshwater shell date } \\
\text { in karstic environment }\end{array}$ \\
\hline Ulu Leang 2 & $8785 \pm 45 \mathrm{BP}$ & Freshwater shell & GRN-8291 & $\begin{array}{l}\text { Bronson and } \\
\text { Glover } 1984\end{array}$ & $\begin{array}{l}\text { Freshwater shell date } \\
\text { in karstic environment }\end{array}$ \\
\hline Paso & $7530 \pm 450 \mathrm{BP}$ & Charcoal & ANU 1517 & Bellwood 1976 & $\begin{array}{l}\text { Standard error in excess } \\
\text { of } 400 \text { years }\end{array}$ \\
\hline Ulu Leang 2 & $7170 \pm 600 \mathrm{BP}$ & Charcoal & ANU 606 & Glover 1978 & $\begin{array}{l}\text { Standard error in excess } \\
\text { of } 400 \text { years }\end{array}$ \\
\hline Gua Mo'o hono & $6855 \pm 32$ BP (AMS) & Freshwater shell & D-AMS 001620 & $\begin{array}{l}0^{\prime} \text { Connor et al. } \\
\text { this volume }\end{array}$ & $\begin{array}{l}\text { Freshwater shell date } \\
\text { in karstic environment }\end{array}$ \\
\hline Gua Mo'o hono & $6808 \pm 28$ BP (AMS) & Freshwater shell & D-AMS 001618 & $\begin{array}{l}0^{\prime} \text { Connor et al. } \\
\text { this volume }\end{array}$ & $\begin{array}{l}\text { Freshwater shell date } \\
\text { in karstic environment }\end{array}$ \\
\hline Gua Mo'o hono & $6531 \pm 28$ BP (AMS) & Freshwater shell & D-AMS 001619a & $\begin{array}{l}\text { o'Connor et al. } \\
\text { this volume }\end{array}$ & $\begin{array}{l}\text { Freshwater shell date } \\
\text { in karstic environment }\end{array}$ \\
\hline
\end{tabular}




\begin{tabular}{|c|c|c|c|c|c|}
\hline Site/ Location & Date & Dating material & Laboratory code & Reference & Reason for rejection \\
\hline Kamassi & $6498 \pm 25$ BP (AMS) & Phytoliths & NZA 34860 & Anggraeni 2012 & $\begin{array}{l}\text { Experimental dating } \\
\text { material }\end{array}$ \\
\hline Leang Burung 1 & $4880 \pm 480 \mathrm{BP}$ & Charcoal & ANU 1264 & $\begin{array}{l}\text { Bulbeck et al. } \\
2000\end{array}$ & $\begin{array}{l}\text { Standard error in excess } \\
\text { of } 400 \text { years }\end{array}$ \\
\hline Gua Móo hono & $4730 \pm 36$ BP (AMS) & Freshwater shell & D-AMS $001616 a$ & $\begin{array}{l}\text { 0'Connor et al. } \\
\text { this volume }\end{array}$ & $\begin{array}{l}\text { Freshwater shell date } \\
\text { in karstic environment }\end{array}$ \\
\hline Gua Móo hono & $4718 \pm 26$ BP (AMS) & Freshwater shell & D-AMS 001624a & $\begin{array}{l}\text { O'Connor et al. } \\
\text { this volume }\end{array}$ & $\begin{array}{l}\text { Freshwater shell date } \\
\text { in karstic environment }\end{array}$ \\
\hline Gua Móo hono & $4702 \pm 29$ BP (AMS) & Freshwater shell & D-AMS 001617 & $\begin{array}{l}\text { O'Connor et al. } \\
\text { this volume }\end{array}$ & $\begin{array}{l}\text { Freshwater shell date } \\
\text { in karstic environment }\end{array}$ \\
\hline Leang Burung 1 & $4610 \pm 220 \mathrm{BP}$ & Human bone apatite & ANU 6175 & $\begin{array}{l}\text { Bulbeck et al. } \\
2000\end{array}$ & Bone apatite fraction \\
\hline Kamassi & $4282 \pm 25$ BP (AMS) & Phytoliths & NZA 34861 & Anggraeni 2012 & $\begin{array}{l}\text { Experimental dating } \\
\text { material }\end{array}$ \\
\hline Kamassi & $4282 \pm 20$ BP (AMS) & Phytoliths & NZA 34896 & Anggraeni 2012 & $\begin{array}{l}\text { Experimental dating } \\
\text { material }\end{array}$ \\
\hline Gua Móo hono & $4202 \pm 31$ BP (AMS) & Freshwater shell & D-AMS 001615 & $\begin{array}{l}\text { O'Connor et al. } \\
\text { this volume }\end{array}$ & $\begin{array}{l}\text { Freshwater shell date } \\
\text { in karstic environment }\end{array}$ \\
\hline Ulu Leang 2 & $\begin{array}{l}\text { 4000-3000 years } \\
\text { ago }\end{array}$ & $\begin{array}{l}\text { Pottery (thermo- } \\
\text { remnant magnetism) }\end{array}$ & Not stated & Glover 1978 & $\begin{array}{l}\text { Date's probability by } \\
\text { half-millennium BP can't } \\
\text { be estimated }\end{array}$ \\
\hline Mansiri & $414 \pm 380 \mathrm{BC}$ & Sediment (OSL) & X6841 & $\begin{array}{l}\text { Azis et al. this } \\
\text { volume }\end{array}$ & $\begin{array}{l}\text { Suspected incomplete } \\
\text { bleaching/no cultural } \\
\text { association }\end{array}$ \\
\hline Gua Móo hono & $1690 \pm 25$ BP (AMS) & Freshwater shell & D-AMS 001614 & $\begin{array}{l}\text { O'Connor et al. } \\
\text { this volume } \\
\end{array}$ & $\begin{array}{l}\text { Freshwater shell date } \\
\text { in karstic environment }\end{array}$ \\
\hline Gua Móo hono & $1568 \pm 21 \mathrm{BP}$ (AMS) & Freshwater shell & D-AMS 001622a & $\begin{array}{l}\text { O'Connor et al. } \\
\text { this volume }\end{array}$ & $\begin{array}{l}\text { Freshwater shell date } \\
\text { in karstic environment }\end{array}$ \\
\hline Mansiri & AD $725 \pm 195$ & Sediment (OSL) & X6839 & $\begin{array}{l}\text { Azis et al. this } \\
\text { volume }\end{array}$ & $\begin{array}{l}\text { Suspected incomplete } \\
\text { bleaching }\end{array}$ \\
\hline Gua Móo hono & $1103 \pm 21 \mathrm{BP}$ (AMS) & Freshwater shell & D-AMS 001612 & $\begin{array}{l}\text { O'Connor et al. } \\
\text { this volume }\end{array}$ & $\begin{array}{l}\text { Freshwater shell date } \\
\text { in karstic environment }\end{array}$ \\
\hline Gua Lampetia & AD $900 \pm 120$ & Burial jar cover (OSL) & UW2871 & $\begin{array}{l}\text { Bulbeck et al. } \\
2016\end{array}$ & $\begin{array}{l}\text { Older of two dates } \\
\text { for same object }\end{array}$ \\
\hline Talaborong & $920 \pm 170 \mathrm{BP}$ & Human bone apatite & ANU 5924 & Bulbeck 1992 & Bone apatite fraction \\
\hline Leang Burung 1 & $660 \pm 200 \mathrm{BP}$ & Human bone apatite & ANU 6173 & $\begin{array}{l}\text { Bulbeck et al. } \\
2000\end{array}$ & Bone apatite fraction \\
\hline Leang Burung 1 & $640 \pm 240 \mathrm{BP}$ & Human bone apatite & ANU 6174 & $\begin{array}{l}\text { Bulbeck et al. } \\
2000\end{array}$ & Bone apatite fraction \\
\hline Toraja region & $650 \pm 40$ BP (AMS) & Cotton patola & 0xA-6482 & Guy 1998 & Ethnographic object \\
\hline Tогаја region & $580 \pm 40 \mathrm{BP}(\mathrm{AMS})$ & Cotton patola & $0 \times A-6481$ & Guy 1998 & Ethnographic object \\
\hline Bulubangi & $570 \pm 60 \mathrm{BP}$ & Human bone & ANU 11852 & $\begin{array}{l}\text { Druce et al. } \\
2005\end{array}$ & $\begin{array}{l}\text { Dating facilities not set } \\
\text { up for human bone }\end{array}$ \\
\hline Poso & 630-470 cal BP & Cotton patola & Not stated & \begin{tabular}{|l} 
Barnes and \\
Kahlenberg 2010 \\
\end{tabular} & Ethnographic object \\
\hline Sulawesi & $550 \pm 40 \mathrm{BP}(\mathrm{AMS})$ & Cotton patola & $0 \times A-5769$ & Guy 1998 & Ethnographic object \\
\hline Тогаја region & $539 \pm 64$ BP (AMS) & Cotton patola & NZA-8090 & Guy 1998 & Ethnographic object \\
\hline Saukang Boe & $450 \pm 220 \mathrm{BP}$ & Human bone apatite & ANU 5923 & Bulbeck 1992 & Bone apatite fraction \\
\hline Poso & 531-323 cal BP & Cotton patola & Not stated & \begin{tabular}{|l} 
Barnes and \\
Kahlenberg 2010 \\
\end{tabular} & Ethnographic object \\
\hline Minahasa & 510-310 cal BP & Cotton patola & Not stated & \begin{tabular}{|l} 
Barnes and \\
Kahlenberg 2010
\end{tabular} & Ethnographic object \\
\hline
\end{tabular}




\begin{tabular}{|c|c|c|c|c|c|}
\hline Site/ Location & Date & Dating material & Laboratory code & Reference & Reason for rejection \\
\hline Sulawesi & $410 \pm 23$ BP (AMS) & Cotton patola & $0 \times A-13343$ & $\begin{array}{l}\text { Higham et al. } \\
2007\end{array}$ & Ethnographic object \\
\hline Palu & 466-287 cal BP & Cotton patola & Not stated & \begin{tabular}{|l|} 
Barnes and \\
Kahlenberg 2010
\end{tabular} & Ethnographic object \\
\hline Sulawesi & $384 \pm 24$ BP (AMS) & Cotton patola & $0 \times A-13297$ & $\begin{array}{l}\text { Higham et al. } \\
2007\end{array}$ & Ethnographic object \\
\hline Sulawesi & $355 \pm 40$ BP (AMS) & Cotton patola & $0 \times A-6484$ & Guy 1998 & Ethnographic object \\
\hline Sulawesi & $295 \pm 55$ BP (AMS) & Cotton patola & $0 \times A-6587$ & Guy 1998 & Ethnographic object \\
\hline Tana Toraja & 346- 170 cal BP & Cotton patola & Not stated & \begin{tabular}{|l|} 
Barnes and \\
Kahlenberg 2010
\end{tabular} & Ethnographic object \\
\hline $\begin{array}{l}\text { Central } \\
\text { Sulawesi }\end{array}$ & $230 \pm 40 \mathrm{BP}$ (AMS) & Cotton patola & $0 \times A-6483$ & Guy 1998 & Ethnographic object \\
\hline $\begin{array}{l}\text { Pontanoa } \\
\text { Bangka }\end{array}$ & $50 \pm 60$ BP (AMS) & Cotton & OZE644 & $\begin{array}{l}\text { Bulbeck and } \\
\text { Caldwell } 2000\end{array}$ & $\begin{array}{l}\text { Larger standard error } \\
\text { than Oxford Laboratory } \\
\text { redating for same } \\
\text { sample }\end{array}$ \\
\hline Rahampu'u 1 & Modern & Charcoal & ANU 11075 & $\begin{array}{l}\text { Bulbeck and } \\
\text { caldwell } 2000\end{array}$ & $\begin{array}{l}\text { No reason to suspect } \\
\text { pre-1950 antiquity }\end{array}$ \\
\hline Katue & Modern & Charcoal (AMS) & $0 Z 0846$ & $\begin{array}{l}\text { Bulbeck and } \\
\text { Caldwell } 2000\end{array}$ & $\begin{array}{l}\text { No reason to suspect } \\
\text { pre-1950 antiquity }\end{array}$ \\
\hline Sabbang Loang & Modern & Charcoal (AMS) & OZE129 & $\begin{array}{l}\text { Bulbeck and } \\
\text { Caldwell } 2000\end{array}$ & $\begin{array}{l}\text { No reason to suspect } \\
\text { pre-1950 antiquity }\end{array}$ \\
\hline $\begin{array}{l}\text { Marante } \\
\text { Tondon }\end{array}$ & Modern & Boat (coffin) & Beta-274723 & Duli 2012 & $\begin{array}{l}\text { No reason to suspect } \\
\text { pre-1950 antiquity }\end{array}$ \\
\hline $\begin{array}{l}\text { Allangkan- } \\
\text { anangnge ri } \\
\text { Latanete }\end{array}$ & Modern & Charcoal (AMS) & Wk-17743 & $\begin{array}{l}\text { Bulbeck et al. } \\
\text { this volume }\end{array}$ & $\begin{array}{l}\text { No reason to suspect } \\
\text { pre-1950 antiquity }\end{array}$ \\
\hline Petta Balubue & Modern & Burnt cranial bone & ANU 5928 & $\begin{array}{l}\text { Kallupa et al. } \\
1989\end{array}$ & $\begin{array}{l}\text { No reason to suspect } \\
\text { pre-1950 antiquity }\end{array}$ \\
\hline Bayoa 1 & Modern & Boat (coffin) & ANU 5926 & Bulbeck 1992 & $\begin{array}{l}\text { No reason to suspect } \\
\text { pre-1950 antiquity }\end{array}$ \\
\hline Batu Ejjaya 2 & Modern & Charcoal & ANU 606 & $\begin{array}{l}\text { Bronson and } \\
\text { Glover } 1984\end{array}$ & $\begin{array}{l}\text { No reason to suspect } \\
\text { pre-1950 antiquity }\end{array}$ \\
\hline
\end{tabular}

Note: Reasons for dates' rejection explained in Bulbeck (2014), except for 'experimental dating material' (Anggraeni 2012), bone apatite fraction (Storm et al. 2013), 'incomplete bleaching of dated sediment' (Azis et al., this volume) and 'ethnographic object' (rather than archaeological status of dated object), which are added here.

Table A8.2: Accepted Holocene radiometric determinations from North and Central Sulawesi (all Carbon-14).

\begin{tabular}{|l|l|l|l|l|l|l|}
\hline Site & Date BP & Laboratory code & Dated material & Site aspect & Site use & Reference \\
\hline Woloan & $1540 \pm 140$ & Not stated & Charcoal & Monumental & Mortuary & Yuniawati 2006 \\
\hline Woloan & $1260 \pm 80$ & Not stated & Human bone & Monumental & Mortuary & Yuniawati 2006 \\
\hline Woloan & $1180 \pm 80$ & Not stated & Human bone & Monumental & Mortuary & Yuniawati 2006 \\
\hline Tatelu & $2070 \pm 140$ & Not stated & Animal bone & Monumental & Mortuary & Yuniawati 2006 \\
\hline Tatelu & $850 \pm 140$ & Not stated & Charcoal & Monumental & Mortuary & Yuniawati 2006 \\
\hline Paso & $7360 \pm 310$ & ANU 1518 & Charcoal & $\begin{array}{l}\text { Freshwater } \\
\text { shell midden }\end{array}$ & Habitation & Bellwood 1976 \\
\hline Teling & $3100 \pm 210$ & Not stated & Charcoal & Open & Habitation & Simanjuntak et al. 2008 \\
\hline Teling & $2770 \pm 120$ & Not stated & Charcoal & Open & Habitation & Simanjuntak 2010 \\
\hline Mansiri & $3035 \pm 35$ (AMS) & S-ANU 40031 & Charcoal & Open & Habitation & Azis et al. this volume \\
\hline Mansiri & $2494 \pm 20$ (AMS) & Wk-44605 & Charcoal & Open & Habitation & Azis et al. this volume \\
\hline
\end{tabular}




\begin{tabular}{|l|l|l|l|l|l|l|}
\hline Site & Date BP & Laboratory code & Dated material & Site aspect & Site use & Reference \\
\hline Mansiri & $2469 \pm 20$ (AMS) & Wk-44610 & Charcoal & Open & Habitation & Azis et al. this volume \\
\hline Pokekea & $1251 \pm 31$ (AMS) & ErL-10584 & Plant matter & Monumental & Ceremonial & Kirleis et al. 2012 \\
\hline Pokekea & $1197 \pm 30($ AMS) & ErL-10585 & Plant matter & Monumental & Ceremonial & Kirleis et al. 2012 \\
\hline Pokekea & $949 \pm 45($ AMS) & ErL-10584 & Plant matter & Monumental & Ceremonial & Kirleis et al. 2012 \\
\hline Pokekea & $890 \pm 30($ AMS) & ErL-10584 & Plant matter & Monumental & Ceremonial & Kirleis et al. 2012 \\
\hline Entovera & $2890 \pm 120$ & Not stated & Charcoal & Monumental & Ceremonial & Simanjuntak 2010 \\
\hline Entovera & $2460 \pm 120$ & Not stated & Charcoal & Monumental & Ceremonial & Simanjuntak 2010 \\
\hline
\end{tabular}

Table A8.3: Accepted Holocene radiometric determinations from West Sulawesi (all Carbon-14).

\begin{tabular}{|c|c|c|c|c|c|c|}
\hline Site & Date BP & Laboratory code & Dated material & Site aspect & Site use & Reference \\
\hline Pantara'an 1 & $2850 \pm 50$ (AMS) & ANU 9707 & Ceramic & Open & Habitation & Anggraeni et al. 2014 \\
\hline Pantara'an 1 & $2505 \pm 25$ (AMS) & ANU 9438 & Ceramic & Open & Habitation & Anggraeni et al. 2014 \\
\hline Pantara'an 1 & $277 \pm 30$ (AMS) & Wk-25697 & Charcoal & Open & Gardening & Anggraeni 2012 \\
\hline $\begin{array}{l}\text { Minangka } \\
\text { Sipakko }\end{array}$ & $2810 \pm 50$ (AMS) & OZE-132 & $\begin{array}{l}\text { Animal matter } \\
\text { (bone) }\end{array}$ & Open & Habitation & $\begin{array}{l}\text { Bulbeck and Nasruddin } \\
2002\end{array}$ \\
\hline $\begin{array}{l}\text { Minangka } \\
\text { Sipakko }\end{array}$ & $2570 \pm 110$ & P3G-97 & Charcoal & Open & Habitation & Simanjuntak 2008 \\
\hline $\begin{array}{l}\text { Minangka } \\
\text { Sipakko }\end{array}$ & $4950 \pm 180$ & P3G-05 & Charcoal & Open & Habitation & Simanjuntak et al. 2008 \\
\hline $\begin{array}{l}\text { Minangka } \\
\text { Sipakko }\end{array}$ & $3690 \pm 160$ & P3G-05 & Charcoal & Open & Habitation & Simanjuntak et al. 2008 \\
\hline $\begin{array}{l}\text { Minangka } \\
\text { Sipakk0 }\end{array}$ & $3446 \pm 51$ (AMS) & Wk-14561 & Charcoal & Open & Habitation & Anggraeni et al. 2014 \\
\hline $\begin{array}{l}\text { Minangka } \\
\text { Sipakko }\end{array}$ & $3343 \pm 46$ (AMS) & Wk-17981 & Charcoal & Open & Habitation & Anggraeni et al. 2014 \\
\hline $\begin{array}{l}\text { Minangka } \\
\text { Sipakk0 }\end{array}$ & $3082 \pm 50$ (AMS) & Wk-14562 & Charcoal & Open & Habitation & Anggraeni et al. 2014 \\
\hline $\begin{array}{l}\text { Minangka } \\
\text { Sipakko }\end{array}$ & $2996 \pm 41$ (AMS) & Wk-14564 & Charcoal & Open & Habitation & Anggraeni et al. 2014 \\
\hline $\begin{array}{l}\text { Minangka } \\
\text { Sipakko }\end{array}$ & $2881 \pm 46$ (AMS) & Wk-14563 & Charcoal & Open & Habitation & Anggraeni et al. 2014 \\
\hline Kamassi & $5830 \pm 140$ & P3G & Charcoal & Open & Habitation & Anggraeni 2012 \\
\hline Kamassi & $3345 \pm 40$ (AMS) & ANU 36406 & Marine shell" $^{*}$ & Open & Habitation & Anggraeni et al. 2014 \\
\hline Kamassi & $3225 \pm 40$ (AMS) & ANU 36406 & $\begin{array}{l}\text { Animal matter } \\
\text { (freshwater shell) }\end{array}$ & Open & Habitation & Anggraeni et al. 2014 \\
\hline Kamassi & $3140 \pm 30$ (AMS) & ANU 35128 & $\begin{array}{l}\text { Animal matter } \\
\text { (freshwater shell) }\end{array}$ & Open & Habitation & Anggraeni et al. 2014 \\
\hline Kamassi & $2700 \pm 150$ (AMS) & Geolabs-411 & Charcoal & Open & Habitation & Anggraeni et al. 2014 \\
\hline Kamassi & $1620 \pm 30$ (AMS) & ANU 35126 & $\begin{array}{l}\text { Animal matter } \\
\text { (freshwater shell) }\end{array}$ & Open & Habitation & Anggraeni et al. 2014 \\
\hline Palemba & $1720 \pm 30$ (AMS) & Beta-360430 & Ceramic & Open & Habitation & Anggraeni 2016 \\
\hline Sakkarra & $2047 \pm 40$ (AMS) \# & S-ANU 39336-2 & Charcoal & Open & Habitation & Fakhri et al. 2015 \\
\hline Sakkarгa & $2000 \pm 40$ (AMS) \# & S-ANU 39336-1 & Charcoal & Open & Habitation & Fakhri et al. 2015 \\
\hline
\end{tabular}

"Calibrated using Marine 0.914c, applied correction factor for marine reservoir effect delta R $89 \pm 70$ (Borneo), assuming 50\% marine contribution.

\#Standard error back-calculated from median age BP and 95\% calibrated range provided by Fakhri et al. (2015). 
Table A8.4: Accepted Holocene radiometric determinations from South Sulawesi north and east of the southwest peninsula (all Carbon-14).

\begin{tabular}{|c|c|c|c|c|c|c|}
\hline Site & Date BP & Laboratory code & Dated material & Site aspect & Site use & Reference \\
\hline Timo'oni & $1854 \pm 25$ (AMS) & Wk-39675 & Charcoal & Monumental & Ceremonial & Fakhri 2016 \\
\hline Timo'oni & $1850 \pm 25$ (AMS) & Wk-39676 & Charcoal & Monumental & Ceremonial & Fakhri 2016 \\
\hline Timo'oni & $1823 \pm 25$ (AMS) & Wk-39677 & Charcoal & Monumental & Ceremonial & Fakhri 2016 \\
\hline Sukoyu & $2070 \pm 50$ & ANU 11271 & Charcoal & Open & Gardening & $\begin{array}{l}\text { Bulbeck and } \\
\text { Caldwell } 2000\end{array}$ \\
\hline Sukoyu & $830 \pm 70$ & ANU 11272 & Charcoal & Open & Industrial & As above \\
\hline Pontanoa Bangka & $1520 \pm 70$ & ANU 11107 & Charcoal & Open & Industrial & As above \\
\hline Pontanoa Bangka & $1010 \pm 60$ & ANU 11108 & Charcoal & Open & Industrial & As above \\
\hline Pontanoa Bangka & $152 \pm 33$ (AMS) & 0xA-10457 & $\begin{array}{l}\text { Plant matter } \\
\text { (cotton) }\end{array}$ & Open & Mortuary & $\begin{array}{l}\text { Higham et al. } \\
2007\end{array}$ \\
\hline Nuha & $960 \pm 70$ & ANU 11105 & Charcoal & Open & Industrial & $\begin{array}{l}\text { Bulbeck and } \\
\text { caldwell } 2000\end{array}$ \\
\hline Nuha & $130 \pm 50$ & ANU 11278 & Charcoal & Open & Industrial & As above \\
\hline Lemogola & $120 \pm 70$ & ANU 11277 & Charcoal & Open & Industrial & As above \\
\hline Rahampu'u 1 & $5680 \pm 130$ & ANU 11802 & Charcoal & Open & Habitation & As above \\
\hline Rahampu'u 1 & $1400 \pm 110$ & ANU 11801 & Charcoal & Open & Habitation & As above \\
\hline Rahampu'u 1 & $1000 \pm 40$ (AMS) & OZE646 & Ceramic & Open & Habitation & As above \\
\hline Rahampu'u 1 & $430 \pm 120$ & ANU 11077 & Charcoal & Open & Industrial & As above \\
\hline Rahampu'u 1 & $400 \pm 60$ & ANU 11080 & Charcoal & Open & Industrial & As above \\
\hline Rahampu'u 1 & $350 \pm 70$ & ANU 11074 & Charcoal & Open & Industrial & As above \\
\hline Rahampu'u 1 & $310 \pm 90$ & ANU 11076 & Charcoal & Open & Industrial & As above \\
\hline Rahampu'u 1 & $310 \pm 90$ & ANU 11079 & Charcoal & Open & Industrial & As above \\
\hline Pandai Besi & $480 \pm 130$ & ANU 11083 & Charcoal & Open & Industrial & As above \\
\hline Pandai Besi & $410 \pm 70$ & ANU 11084 & Charcoal & Open & Industrial & As above \\
\hline Matano bore & $2350 \pm 140$ & ANU 11104 & Charcoal & Open & Gardening & As above \\
\hline Turungang Damar & $350 \pm 70$ & ANU 11353 & Charcoal & Open & Habitation & As above \\
\hline Manu Manue & $170 \pm 70$ (AMS) & $0 Z 0848$ & Charcoal & Open & Habitation & As above \\
\hline Katue & $1850 \pm 40$ (AMS) & OZE581 & Charcoal & Open & Habitation & As above \\
\hline Katue & $1810 \pm 40$ (AMS) & OZD847 & Charcoal & Open & Habitation & As above \\
\hline Katue & $1100 \pm 50$ (AMS) & $0 Z D 845$ & $\begin{array}{l}\text { Charcoal } \\
\text { (carbonised shell) }\end{array}$ & Open & Habitation & As above \\
\hline Katue & $370 \pm 35$ (AMS) & OZE580 & Charcoal & Open & Gardening & As above \\
\hline Bola Merajae & $1980 \pm 90$ (AMS) & $0 Z 0843$ & Charcoal & Open & Habitation & As above \\
\hline Bola Merajae & $1870 \pm 40$ (AMS) & OZE579 & Charcoal & Open & Habitation & As above \\
\hline Bola Merajae & $1260 \pm 60$ (AMS) & $0 Z 0844$ & Charcoal & Open & Habitation & As above \\
\hline Bola Merajae & $660 \pm 70$ & ANU 11356 & Charcoal & Open & Habitation & As above \\
\hline Bola Merajae & $310 \pm 40$ (AMS) & OZE578 & Charcoal & Open & Habitation & As above \\
\hline Salabu & $400 \pm 60$ (AMS) & Wk-7336 & Animal (dentine) & \begin{tabular}{|l} 
Marine shell \\
midden
\end{tabular} & Habitation & As above \\
\hline Pinanto & $390 \pm 90$ & ANU 11355 & Charcoal & Open & Habitation & As above \\
\hline Sabbang Loang & $2020 \pm 140$ & ANU 11106 & Charcoal & Open & Mortuary & As above \\
\hline Sabbang Loang & $1990 \pm 200$ & ANU 11273 & Charcoal & Open & Mortuary & As above \\
\hline Sabbang Loang & $1910 \pm 70$ (AMS) & OZD850 & Ceramic & Open & Habitation & As above \\
\hline Sabbang Loang & $1780 \pm 50$ (AMS) & $0 Z 0851$ & Ceramic & Open & Habitation & As above \\
\hline Sabbang Loang & $1750 \pm 50$ (AMS) & OZD852 & Ceramic & Open & Habitation & As above \\
\hline Arateng & $450 \pm 60$ & ANU 11109 & Boat (coffin) & Open & Mortuary & As above \\
\hline
\end{tabular}




\begin{tabular}{|c|c|c|c|c|c|c|}
\hline Site & Date BP & Laboratory code & Dated material & Site aspect & Site use & Reference \\
\hline Gua Andomo & $1000 \pm 25$ (AMS) & SANU 34619 & Human bone & Closed & Mortuary & $\begin{array}{l}\text { Bulbeck et al. } \\
2016\end{array}$ \\
\hline Tampang Allo & $1070 \pm 50$ & Beta-281928 & Boat (coffin) & Closed & Mortuary & Duli 2012 \\
\hline $\begin{array}{l}\text { Marimbunna } \\
\text { Tikala }\end{array}$ & $1130 \pm 50$ & Beta-287186 & Boat (coffin) & Closed & Mortuary & Duli 2012 \\
\hline Londa & $1000 \pm 40$ & Beta-274728 & Boat (coffin) & Closed & Mortuary & Duli 2012 \\
\hline Lombok Borik & $930 \pm 40$ & Beta-274725 & Boat (coffin) & Closed & Mortuary & Duli 2012 \\
\hline Buntu Pune & $810 \pm 50$ & Beta-281927 & Boat (coffin) & Closed & Mortuary & Duli 2012 \\
\hline Marante Tondon & $800 \pm 50$ & Beta-287188 & Boat (coffin) & Closed & Mortuary & Duli 2012 \\
\hline Lalanbai Sarira & $780 \pm 60$ & Beta-294688 & Boat (coffin) & Closed & Mortuary & Duli 2012 \\
\hline Lalik Manuk & $710 \pm 40$ & Beta-294684 & Boat (coffin) & Closed & Mortuary & Duli 2012 \\
\hline $\begin{array}{l}\text { Tambolang } \\
\text { Ba'lele }\end{array}$ & $660 \pm 40$ & Beta-294687 & Boat (coffin) & Closed & Mortuary & Duli 2012 \\
\hline Lalik Manuk & $640 \pm 50$ & Beta-287183 & Boat (coffin) & Closed & Mortuary & Duli 2012 \\
\hline Limbong & $570 \pm 50$ & Beta-287189 & Boat (coffin) & Closed & Mortuary & Duli 2012 \\
\hline $\begin{array}{l}\text { Allak Angin- } \\
\text { Angin }\end{array}$ & $510 \pm 50$ & Beta-287187 & Boat (coffin) & Closed & Mortuary & Duli 2012 \\
\hline Lombok Borik & $400 \pm 50$ & Beta-274726 & Boat (coffin) & Closed & Mortuary & Duli 2012 \\
\hline Ke'te Kesuk & $400 \pm 50$ & Beta-274726 & Boat (coffin) & Closed & Mortuary & Duli 2012 \\
\hline $\begin{array}{l}\text { Marimbunna } \\
\text { Tikala }\end{array}$ & $390 \pm 50$ & Beta-287185 & Boat (coffin) & Closed & Mortuary & Duli 2012 \\
\hline Lo'kok Pongdadu & $360 \pm 50$ & Beta-294686 & Boat (coffin) & Closed & Mortuary & Duli 2012 \\
\hline Lombok Borik & $360 \pm 50$ & Beta-281929 & Boat (coffin) & Closed & Mortuary & Duli 2012 \\
\hline Se'pon Marinding & $360 \pm 40$ & Beta-294685 & Boat (coffin) & Closed & Mortuary & Duli 2012 \\
\hline $\begin{array}{l}\text { Pangki } \\
\text { Mangke'pek }\end{array}$ & $350 \pm 60$ & Beta-294689 & Boat (coffin) & Closed & Mortuary & Duli 2012 \\
\hline Tampang Allo & $310 \pm 40$ & Beta-274727 & Boat (coffin) & Closed & Mortuary & Duli 2012 \\
\hline Palak Tokkek & $280 \pm 40$ & Beta-274724 & Boat (coffin) & Closed & Mortuary & Duli 2012 \\
\hline $\begin{array}{l}\text { Potok Tengan } \\
\text { Kando }\end{array}$ & $240 \pm 40$ & Beta-287184 & Boat (coffin) & Closed & Mortuary & Duli 2012 \\
\hline Tok Sempa & $790 \pm 50$ & Beta-274731 & Boat (coffin) & Closed & Mortuary & Duli 2013 \\
\hline Kaluppini & $790 \pm 50$ & Beta-274732 & Boat (coffin) & Closed & Mortuary & Duli 2013 \\
\hline $\begin{array}{l}\text { Marengok } \\
\text { Papaling } \\
\end{array}$ & $700 \pm 40$ & Beta-274729 & Boat (coffin) & Closed & Mortuary & Duli 2013 \\
\hline Puang Leoran & $700 \pm 40$ & Beta-274730 & Boat (coffin) & Closed & Mortuary & Duli 2013 \\
\hline Buttu Mila & $570 \pm 40$ & Beta-274733 & Boat (coffin) & Closed & Mortuary & Duli 2013 \\
\hline Liang Datu & $470 \pm 40$ & Beta-274734 & Boat (coffin) & Closed & Mortuary & Duli 2013 \\
\hline
\end{tabular}

Table A8.5: Accepted Holocene radiometric determinations from Southeast Sulawesi (all Carbon-14 unless otherwise stated).

\begin{tabular}{|l|l|l|l|l|l|l|}
\hline Site & Date BP & Laboratory code & Dated material & Site aspect & Site use & Reference \\
\hline Gua Lampetia & $890 \pm 100$ & UW2870 (OSL) & Ceramic & Closed & Mortuary & Bulbeck et al. 2016 \\
\hline Gua Talimbue & $8735 \pm 38$ & D-AMS 004042 & Charcoal & Closed & Habitation & O'Connor et al. 2014 \\
\hline Gua Talimbue & $8526 \pm 42$ & D-AMS 004040 & Charcoal & Closed & Habitation & O'Connor et al. 2014 \\
\hline Gua Talimbue & $8191 \pm 33$ & D-AMS 004039 & Charcoal & Closed & Habitation & O'Connor et al. 2014 \\
\hline Gua Talimbue & $7961 \pm 39$ & D-AMS 004038 & Charcoal & Closed & Habitation & O'Connor et al. 2014 \\
\hline Gua Talimbue & $6506 \pm 38$ & D-AMS 004037 & Charcoal & Closed & Habitation & O'Connor et al. 2014 \\
\hline Gua Talimbue & $6127 \pm 31$ & D-AMS 004036 & Charcoal & Closed & Habitation & O'Connor et al. 2014 \\
\hline Gua Talimbue & $5973 \pm 30$ & D-AMS 004035 & Charcoal & Closed & Habitation & O'Connor et al. 2014 \\
\hline
\end{tabular}




\begin{tabular}{|c|c|c|c|c|c|c|}
\hline Site & Date BP & Laboratory code & Dated material & Site aspect & Site use & Reference \\
\hline Gua Talimbue & $5740 \pm 36$ & D-AMS 004034 & Charcoal & Closed & Habitation & O'Connor et al. 2014 \\
\hline Gua Talimbue & $3923 \pm 30$ & D-AMS 004032 & Charcoal & Closed & Habitation & 0'Connor et al. 2014 \\
\hline Gua Talimbue & $3843 \pm 29$ & D-AMS 004031 & Charcoal & Closed & Habitation & 0'Connor et al. 2014 \\
\hline Gua Talimbue & $3800 \pm 28$ & D-AMS 004033 & Charcoal & Closed & Habitation & 0'Connor et al. 2014 \\
\hline Gua Talimbue & $3767 \pm 29$ & D-AMS 004029 & Charcoal & Closed & Habitation & 0'Connor et al. 2014 \\
\hline Gua Talimbue & $3733 \pm 29$ & D-AMS 004030 & Charcoal & Closed & Habitation & o'Connor et al. 2014 \\
\hline Gua Talimbue & $3726 \pm 33$ & D-AMS 004041 & Charcoal & Closed & Habitation & o'Connor et al. 2014 \\
\hline Gua Talimbue & $3372 \pm 27$ & D-AMS 004028 & Charcoal & Closed & Habitation & Bulbeck et al. 2016 \\
\hline Gua Talimbue & $1710 \pm 20$ & SANU 40418 & Human bone & Closed & Mortuary & Bulbeck et al. 2016 \\
\hline Gua Talimbue & $347 \pm 26$ & D-AMS 004027 & Charcoal & Closed & Habitation & Bulbeck et al. 2016 \\
\hline Gua Mo'o hono & $5618 \pm 29$ & D-AMS 001627 & Charcoal & Closed & Habitation & $0^{\prime}$ Connor et al. this volume \\
\hline Gua Mo'o hono & $5461 \pm 29$ & D-AMS 001625 & Charcoal & Closed & Habitation & $0^{\prime}$ Connor et al. this volume \\
\hline Gua Móo hono & $5460 \pm 32$ & D-AMS 001621 & Charcoal & Closed & Habitation & $0^{\prime}$ Connor et al. this volume \\
\hline Gua Mo'o hono & $5371 \pm 28$ & D-AMS 001619 & Charcoal & Closed & Habitation & $0^{\prime}$ Connor et al. this volume \\
\hline Gua Móo hono & $5214 \pm 32$ & D-AMS 001626 & Charcoal & Closed & Habitation & $0^{\prime}$ Connor et al. this volume \\
\hline Gua Mo'o hono & $3905 \pm 26$ & D-AMS 001616 & Charcoal & Closed & \begin{tabular}{|l|} 
Habitation \\
\end{tabular} & $0^{\prime}$ Connor et al. this volume \\
\hline Gua Móo hono & $3870 \pm 40$ & SANU 10573 & $\begin{array}{l}\text { Animal matter } \\
\text { (tooth) }\end{array}$ & Closed & Habitation & $\mathrm{O}^{\prime}$ Connor et al. this volume \\
\hline Gua Móo hono & $3865 \pm 29$ & D-AMS 001624 & Charcoal & Closed & Habitation & $\mathrm{O}^{\prime}$ Connor et al. this volume \\
\hline Gua Móo hono & $3452 \pm 26$ & D-AMS 001623 & Charcoal & Closed & Habitation & Bulbeck et al. 2016 \\
\hline Gua Móo hono & $450 \pm 24$ & D-AMS 001622 & Charcoal & Closed & Habitation & Bulbeck et al. 2016 \\
\hline Gua Sambangoala & $4923 \pm 30$ & D-AMS 001993 & Charcoal & Closed & Habitation & Fakhri this volume \\
\hline Gua Sambangoala & $4802 \pm 26$ & D-AMS 001994 & Charcoal & Closed & \begin{tabular}{|l|} 
Habitation \\
\end{tabular} & Fakhri this volume \\
\hline Gua Sambangoala & $4766 \pm 31$ & D-AMS 001991 & Charcoal & Closed & Habitation & Fakhri this volume \\
\hline Gua Sambangoala & $4482 \pm 28$ & D-AMS 001992 & Charcoal & Closed & Habitation & Fakhri this volume \\
\hline Gua Sambangoala & $3925 \pm 29$ & D-AMS 001989 & Charcoal & Closed & Habitation & Fakhri this volume \\
\hline Gua Sambangoala & $3883 \pm 29$ & D-AMS 001990 & Charcoal & Closed & Habitation & Fakhri this volume \\
\hline Gua Sambangoala & $3297 \pm 29$ & D-AMS 001988 & Charcoal & Closed & Habitation & Fakhri this volume \\
\hline Gua Tengkorak & $7239 \pm 36$ & D-AMS 009676 & Charcoal & Closed & Habitation & Ugo Zoppi pers. comm. \\
\hline Gua Tengkorak & $7139 \pm 35$ & D-AMS 009675 & Charcoal & Closed & Habitation & Ugo Zoppi pers. comm. \\
\hline
\end{tabular}

Table A8.6: Accepted Holocene radiometric determinations from the South Sulawesi southwest peninsula (all Carbon-14).

\begin{tabular}{|c|c|c|c|c|c|c|}
\hline Site & Date BP & Laboratory code & Dated material & Site aspect & Site use & Reference \\
\hline Bulubangi & $270 \pm 140 \mathrm{BP}$ & ANU-11853 & Charcoal & Open & Mortuary & Druce et al. 2005 \\
\hline $\begin{array}{l}\text { Allangkan-anangnge } \\
\text { ri Latanete }\end{array}$ & $955 \pm 30$ (AMS) & Wk-19966 & $\begin{array}{l}\text { Animal matter } \\
\text { (marine shell): }\end{array}$ & Open & Habitation & $\begin{array}{l}\text { Bulbeck et al. this } \\
\text { volume }\end{array}$ \\
\hline $\begin{array}{l}\text { Allangkan-anangnge } \\
\text { ri Latanete }\end{array}$ & $820 \pm 60$ & ANU 11352 & $\begin{array}{l}\text { Animal matter } \\
\text { (marine shell)* }\end{array}$ & Open & Habitation & $\begin{array}{l}\text { Bulbeck and } \\
\text { Caldwell } 2008 \\
\end{array}$ \\
\hline $\begin{array}{l}\text { Allangkan-anangnge } \\
\text { ri Latanete }\end{array}$ & $752 \pm 34$ (AMS) & Wk-17818 & Charcoal & Open & Industrial & \begin{tabular}{|l}
$\begin{array}{l}\text { Bulbeck et al. this } \\
\text { volume }\end{array}$ \\
\end{tabular} \\
\hline $\begin{array}{l}\text { Allangkan-anangnge } \\
\text { ri Latanete }\end{array}$ & $364 \pm 25$ (AMS) & Wk-29737 & Charcoal & Open & Mortuary & $\begin{array}{l}\text { Bulbeck et al. this } \\
\text { volume }\end{array}$ \\
\hline Tinco Tua & $762 \pm 30$ (AMS) & Beta-324215 & Charcoal & Monumental & Ceremonial & Hasanuddin 2015 \\
\hline Tinco Tua & $380 \pm 30$ (AMS) & Beta-324216 & Charcoal & Open & Habitation & Hasanuddin 2015 \\
\hline Tinco Tua & $320 \pm 30$ (AMS) & Beta-324217 & Charcoal & Monumental & Ceremonial & Hasanuddin 2015 \\
\hline Mallawa & $3580 \pm 130$ & P3G-06 & Charcoal & Open & Habitation & Simanjuntak 2008 \\
\hline Mallawa & $2710 \pm 170$ & P3G-06 & Charcoal & Open & Habitation & Simanjuntak 2008 \\
\hline Mallawa & $2490 \pm 220$ & ANU 11276 & Charcoal & Open & Habitation & Bulbeck 2004 \\
\hline
\end{tabular}




\begin{tabular}{|c|c|c|c|c|c|c|}
\hline Site & Date BP & Laboratory code & Dated material & Site aspect & Site use & Reference \\
\hline Mallawa & $2281 \pm 46$ & Wk-20380 & Charcoal & Open & Habitation & Hakim et al. 2009 \\
\hline Mallawa & $1860 \pm 70$ & ANU 11274 & Charcoal & Open & Habitation & Bulbeck 2004 \\
\hline Mallawa & $576 \pm 80$ & ANU 11275 & Charcoal & Open & Habitation & Bulbeck 2004 \\
\hline Gua Pasaung & $6026 \pm 70$ (AMS) & Wk-20381 & Charcoal & Closed & Habitation & Hakim et al. 2009 \\
\hline Ulu Leang 1 & $5740 \pm 230$ & ANU 394 & Charcoal & Closed & Habitation & Bulbeck et al. 2000 \\
\hline Ulu Leang 1 & $4390 \pm 110$ & PRL-231 & Charcoal & Closed & Habitation & Bulbeck et al. 2000 \\
\hline Ulu Leang 1 & $4050 \pm 90$ & HAR-1734 & Charcoal & Closed & Habitation & Bulbeck et al. 2000 \\
\hline Ulu Leang 1 & $3550 \pm 130$ & PRL-230 & Charcoal & Closed & Habitation & Bulbeck et al. 2000 \\
\hline Ulu Leang 1 & $1490 \pm 210$ & SUA-1080 & Charcoal & Closed & Habitation & Bulbeck et al. 2000 \\
\hline Leang Burung 1 & $3420 \pm 400$ & ANU 390 & Charcoal & Closed & Habitation & Bulbeck et al. 2000 \\
\hline Leang Burung 1 & $2820 \pm 210$ & ANU 391 & Charcoal & Closed & Habitation & Bulbeck et al. 2000 \\
\hline Leang Burung 1 & $2260 \pm 90$ & ANU 6173 & $\begin{array}{l}\text { Human bone } \\
\text { collagen }\end{array}$ & Closed & Mortuary & Bulbeck et al. 2000 \\
\hline Leang Burung 1 & $1660 \pm 190$ & ANU 6174 & $\begin{array}{l}\text { Human bone } \\
\text { collagen }\end{array}$ & Closed & Mortuary & Bulbeck et al. 2000 \\
\hline Leang Burung 1 & $1160 \pm 200$ & ANU 6172 & $\begin{array}{l}\text { Human bone } \\
\text { collagen }\end{array}$ & Closed & Mortuary & Bulbeck et al. 2000 \\
\hline Leang Burung 2 & $1665 \pm 80$ & T-9096 & Charcoal & Closed & Habitation & Glover 1981 \\
\hline Leang Burung 2 & $1275 \pm 5$ & Not stated & Charcoal & Closed & Habitation & Glover 1981 \\
\hline Leang Karassak & $2690 \pm 60$ (AMS) & Wk-3823 & Charcoal & Closed & Habitation & Bulbeck et al. 2000 \\
\hline Leang Karassak & $370 \pm 50$ (AMS) & Wk-3824 & Charcoal & Closed & Habitation & Bulbeck et al. 2000 \\
\hline Gua Batti & $2928 \pm 26$ (AMS) & Wk-30264 & Charcoal & Closed & Habitation & $\begin{array}{l}\text { Oktaviana et al. } \\
2016\end{array}$ \\
\hline Lamuru & $340 \pm 70$ & ANU 5922 & Boat (coffin) & Open & Mortuary & Bulbeck 1992 \\
\hline Вауоа & $270 \pm 120$ & ANU 5927 & Boat (coffin) & Open & Mortuary & Bulbeck 1992 \\
\hline Bonto-Bontoa & $170 \pm 55$ & 0ZE-130 & Charcoal & Open & Gardening & \begin{tabular}{|l} 
Bulbeck and \\
Fadillah 2000 \\
\end{tabular} \\
\hline Galesong & $1910 \pm 90$ (AMS) & Oxford & Ceramic & Open & Ceremonial & Glover 1997 \\
\hline Near Galesong & $1640 \pm 70$ (AMS) & Not stated & Ceramic & Open & Ceremonial & Glover 1997 \\
\hline Bayoa, Sanrabone & $780 \pm 80$ & ANU 5564 & Boat (coffin)\# & Open & Mortuary & Bulbeck 1992 \\
\hline Batu Ejayya 1 & $4430 \pm 50$ (AMS) & Wk-5464 & Marine shell" & Closed & Habitation & Bulbeck et al. 2000 \\
\hline Batu Ejayya 1 & $4370 \pm 70$ (AMS) & Wk-5465 & Marine shell" & Closed & Habitation & Bulbeck et al. 2000 \\
\hline Batu Ejaуyа 1 & $920 \pm 275$ & ANU 392 & Charcoal & Closed & Ceremonial & Bulbeck et al. 2000 \\
\hline Leang Batu Tunpa & $500 \pm 33$ (AMS) & Wk-15438 & $\begin{array}{l}\text { Human bone } \\
\text { (dentine) }\end{array}$ & Closed & Mortuary & $\begin{array}{l}\text { Bulbeck and Hakim } \\
2005\end{array}$ \\
\hline
\end{tabular}

"Calibrated using Marine 0.914c, applied correction factor for marine reservoir effect delta R 89 \pm 70 (Borneo), assuming 50\% marine contribution.

\#80 years subtracted from calibrated date to allow for 80 countable tree rings ('old wood effect') between radiocarbon-dated wood sample and tree heart. 
This text is taken from The Archaeology of Sulawesi: Current Research on the Pleistocene to the Historic Period, edited by Sue O'Connor, David Bulbeck and Juliet Meyer, published 2018 by ANU Press, The Australian National University, Canberra, Australia.

doi.org/10.22459/TA48.11.2018.08 